\title{
15. EOCENE TO PLIOCENE ARCHAEOMONADS, EBRIDIANS, AND ENDOSKELETAL DINOFLAGELLATES FROM THE NORWEGIAN SEA, DSDP LEG 38
}

\author{
Katharina Perch-Nielsen, Department of Geology, Swiss Federal Institute of Technology, \\ Zürich, Switzerland and Institute of Historical Geology and Paleontology, Copenhagen. Denmark
}

\begin{abstract}
Eocene to Pliocene archaeomonads, ebridians, endoskeletal dinoflagellates, and some siliceous microfossils of uncertain affinity found in siliceous sequences cored on DSDP Leg 38 in the Norwegian Sea are listed and illustrated. The diversity of forms is highest in the Eocene sequences and decreases in younger sediments. The diversity is generally lower than in the somewhat lower southern latitude material studied from DSDP Leg 29 from the subantarctic southwest Pacific and New Zealand. Six new archaeomonads, three new ebridians, and one new endoskeletal dinoflagellate are described.
\end{abstract}

\section{INTRODUCTION}

Besides the better known and more often studied Radiolaria, diatoms, and silicoflagellates, some smaller groups of siliceous micro- and nannofossils are commonly found in diatom-rich sediments: archaeomonads, ebridians, and endoskeletal dinoflagellates. Their presence is rarely mentioned in DSDP reports, as they do not occur in large enough amounts to be noted by the sedimentologists. However, sediment layers consisting solely of archaeomonads are known to exist.

These groups were studied in Upper Cretaceous to Pleistocene siliceous sediments from the subantarctic southwest Pacific at latitudes of $40^{\circ}$ to $55^{\circ} \mathrm{S}$ (PerchNielsen, 1975). Previously, Dumitrica (1973) reported on ebridians and endoskeletal dinoflagellates from the southwestern Pacific (DSDP Leg 21), and Ling (1973, DSDP Leg 19) discussed ebridians from the North Pacific. It was therefore of great interest to study these groups from high northern latitude sites in the Atlantic and to compare the findings with the results from the high southern latitudes presented in Perch-Nielsen (1975).

\section{Methods of Study}

Smear slides were prepared for all samples and studied by light microscope. Samples from Sites 338341 , especially rich in archaeomonads, ebridians, or endoskeletal dinoflagellates or showing one of them in better than average preservation, were treated with diluted $\mathrm{HCl}$ and washed several times with water by centrifuging. A drop of the residue was then put on a round cover slide and mounted on a stub for observation in the SEM.

\section{Samples}

Samples were studied from the sites listed in Table 1. Cores containing archaeomonads and/or ebridians and/or endoskeletal dinoflagellates are also listed. The
TABLE 1

Cores Studied From Leg 38 Sites for Archaeomonads, Ebridians, or Endoskeletal Dinoflagellates

\begin{tabular}{|c|c|c|c|}
\hline Site & Cores & $\begin{array}{l}\text { Method of } \\
\text { Study }\end{array}$ & Age \\
\hline 338 & $\begin{array}{l}8-29(9,10,12,24,25, \\
28 \text { not seen) }\end{array}$ & LM, SEM & $\begin{array}{l}\text { L. Eocene to } \\
\text { M. Miocene }\end{array}$ \\
\hline 339 & $8,11(7,9,10,12$ not seen $)$ & LM, SEM & $\begin{array}{l}\text { L. Eocene or } \\
\text { Oligocene }\end{array}$ \\
\hline 340 & $2-11$ (6 not seen) & LM, SEM & L. Eocene \\
\hline 341 & $26-34$ & LM, SEM & M. Miocene \\
\hline 342 & $3-6$ & $\mathrm{LM}$ & E. Miocene \\
\hline 346 & $6-9,11$ & LM & M. Miocene \\
\hline 348 & $\begin{array}{l}5-7,11,13-16(10,12,17, \\
18 \text { not seen })\end{array}$ & LM & $\begin{array}{l}\text { M. Miocene to } \\
\text { Pleistocene }\end{array}$ \\
\hline
\end{tabular}

fossils were not found at Sites $343,344,347,349$, and 350. The site localities are shown in Figure 1.

\section{SPECIFIC RESULTS FOR SITES 346 AND 348}

\section{Site 346}

Site 346 was located on the Jan Mayen Ridge in a water depth of 732 meters. Cores 5 and 6 belong to the silicoflagellate zone of Corbisema triacantha of early to middle Miocene age. Cores below Sample 12, CC could not be assigned to any silicoflagellate zone. The siliceous assemblage contains mainly diatoms. Sponge spicules are often common. The presence of common sponge spicules is often a sign of solution of the other, more delicate siliceous components of the sediment. Thus, no ebridians were found, only few and poorly preserved archaeomonads are present. No endoskeletal dinoflagellates were observed. The archaeomonads include Archaeomonas dubia in Samples 346-6-3, $65 \mathrm{~cm}$; $346-7-3,110 \mathrm{~cm}$; and $346-11-3,110 \mathrm{~cm}$. A. cf. $A$. semplica is present in the first two of the listed samples, and Archaeomonas sp. is found in Sample 346-7-3, 110 $\mathrm{cm}$. Archaeosphaeridium ornatum was found only in 


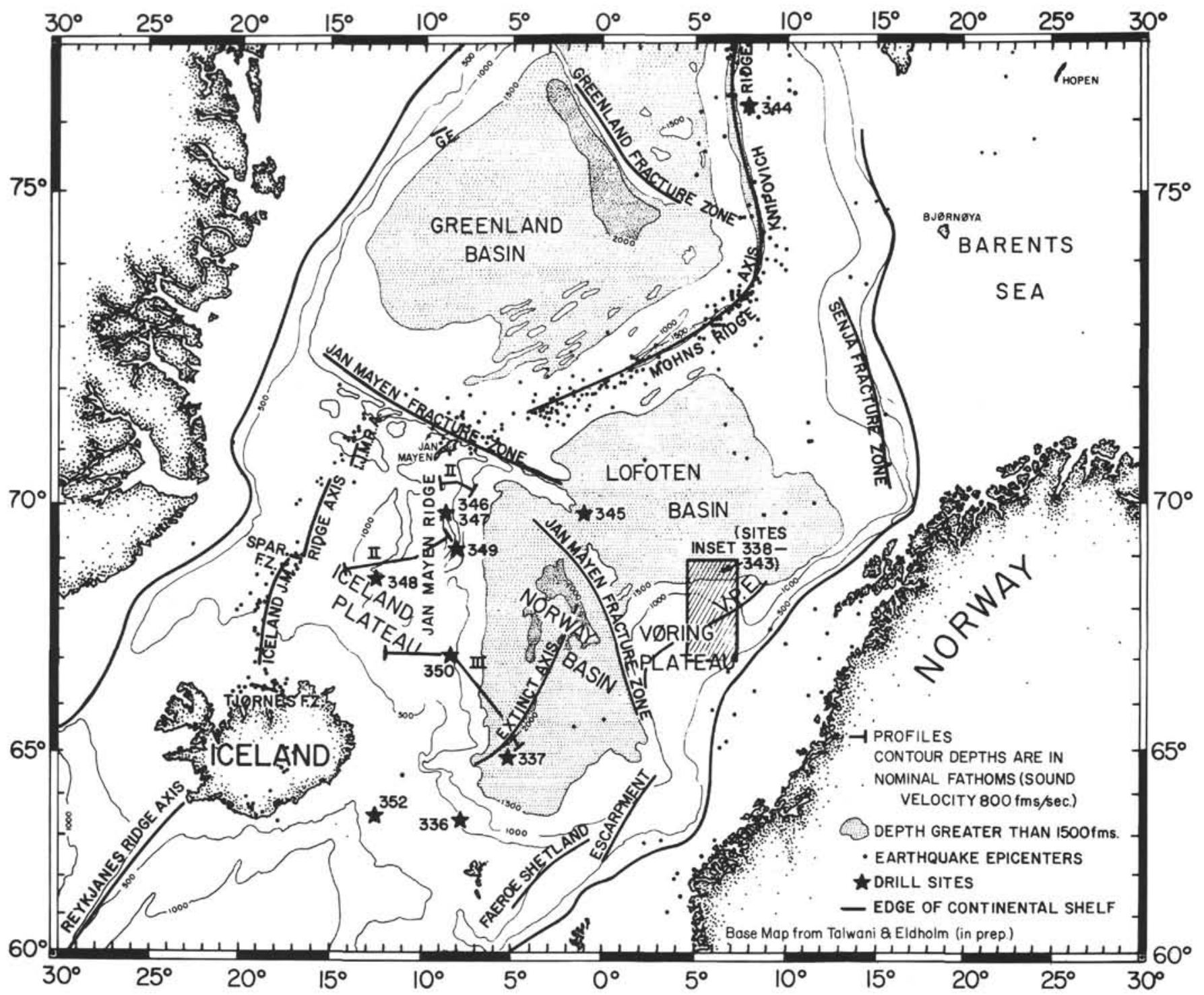

Figure 1. Map showing sites drilled on Deep Sea Drilling Project, Leg 38.

Sample $346-9-3,145 \mathrm{~cm}$ and is the only archaeomonad species in this sample that could survive the apparent solution.

\section{Site 348}

Site 348 was located on the Icelandic Plateau in a water depth of 1763 meters. Archaeomonads, ebridians, and endoskeletal dinoflagellates were found in most siliceous samples studied from Cores 5 through 16. The occurrence of common archaeomonads in the two uppermost cores is of special interest, since Core 348-5 is assigned to the Distephanus speculum Zone of silicoflagellates which is given a Pliocene or Pleistocene age, and Core $348-6$ is assigned to the Distephanus boliviensis Zone (uppermost Miocene to lower Pliocene). Except for archaeomonads from questionable Pliocene from DSDP Site 278 in the subantarctic southwest Pacific, no archaeomonads younger than Miocene have been reported. If the age assignment here is correct, the range of archaeomonads can be extended at least into the Pliocene. Besides Archaeomonas dubia, which occurs in most samples, $A$. cf. $A$. semplicia was found, and Archaeosphaeridium ornatum was found in Sample 348-14-3, $80 \mathrm{~cm}$, of middle or late Miocene age.

Ammodochium rectangulare and Ebriopsis crenulata occur sporadically and Pseudammodochium cf. $P$. dictyoides was found only in Sample 348-6-3, $15 \mathrm{~cm}$. Actiniscus pentasterias is present in all siliceous samples, A. tetrasterias only in Sample 348-11-3, $95 \mathrm{~cm}$.

\section{ARCHAEOMONADS}

The Archaeomonadaceae are a family of fossil marine chrysomonadins which, during their life cycle, formed cysts consisting of $\mathrm{SiO}_{2}$. The archaeomonads probably led a planktonic life in the photic zone of the oceans and their cysts had an opening. The form and size of the opening, as well as of the cyst, are used to distinguish genera and species. Archaeomonads occur from the Late Cretaceous through the Miocene and possibly Pliocene (Tynan, 1971; Perch-Nielsen, 1975). 


\section{Late Eocene}

Siliceous sediments of late Eocene age were recorded at Sites 338, 339, and 340. They yielded rare to common archaeomonads, the assemblage typically including Archaeomonas striata, A. heteroptera, and A. ninae. Six new species are described from the late Eocene to early Oligocene. The late Eocene to early Oligocene (late Eocene and early Oligocene cannot be distinguished by silicoflagellates which were used for the age determination in most cases) archaeomonad assemblages are different and richer than those reported from the subantarctic southwest Pacific (Perch-Nielsen, 1975), although some species are in common.

\section{Oligocene}

Oligocene siliceous sediments were cored at Sites 338, 339, and 346 and include less diverse archaeomonad assemblages than the late Eocene or most of the Miocene studied from the Norwegian Sea. The assemblage is especially poor in the interval assigned by silicoflagellates to the middle Oligocene, whereas it is richer in the intervals assigned to "late Eocene to early Oligocene" and "late Oligocene to early Miocene," the latter boundary being comprised within a silicoflagellate zone. Also, the Oligocene archaeomonad assemblage differs from the one described from the subantarctic southwest Pacific. Most conspicuous is the absence of Archaeosphaeridium tasmaniae and $A$. australensis in the Oligocene of the Norwegian Sea.

\section{Miocene}

The Miocene siliceous sequences of Sites 338, 341, 342,346 , and 348 were studied for this report. Archaeomonads are absent or rare to common, and the diversity is higher than in the Oligocene, but considerably lower than in the late Eocene. Diversity and abundance are highest in the middle Miocene, a fact already observed in most Miocene sequences studied for archaeomonads. In fact, most Miocene archaeomonads described are from the middle Miocene.

\section{Pliocene-Pleistocene}

Pliocene-Pleistocene siliceous sediments were cored at Site 348 and dated by silicoflagellate zonation (Distephanus speculum Zone). If this age assignment is correct, the archaeomonads found in Cores 348-5 and 348-6 are the youngest yet observed-Archaeomonas dubia, and a form very similar to $A$. dubia, but with somewhat more robust spines. These forms could, however, also be reworked since they occur in a sediment with a considerable amount of clastic material.

\section{SYSTEMATIC PALEONTOLOGY}

The taxonomy used in this report was proposed by Deflandre (1932a), who also is the author of most species found in the siliceous sediments studied from DSDP Leg 38 . It is based mainly on the morphology and geometry of the siliceous cysts and their opening. All species described before 1969 are illustrated in Deflandre and Deflandre-Rigaud (1970), and their stratigraphic distribution is compiled in Tynan (1971). A discussion of the Chrysomonad cyst-families Chrysostomataceae and Archaeomonadaceae and their status in paleontology is given by Cornell (1970), who also discusses their biology.

\section{Genus ARCHAEOMONADOPSIS Deflandre, 1938}

\section{Archaeomonadopsis lagenula Deflandre, 1938}

(Plate 3, Figure 20)

Remarks: A. lagenula, an easily recognizable, large form, was described from the upper Eocene diatomite of Oamaru, New Zealand, and was found in the upper Eocene sediments at Site 340 on the V $\phi$ ring Plateau.

\section{Genus ARCHAEOMONAS Deflandre, 1932a}

Archaeomonas areolata Deflandre, 1933

(Plate 1, Figures 5-8, 10; Plate 4, Figures 2, 3)

Remarks: $A$. areolata was originally described from the MioPliocene of Karand, Hungary, and was found in the Miocene at Site 338 on the V $\phi$ ring Plateau. The SEM pictures on Plate 1 show different states of preservation of this species from the well-preserved specimen in Figure 6 to the poorly preserved form in Figure 10.

\section{Archaeomonas chenevieri Deflandre, 1932e}

(Plate 3, Figures 11, 12)

Remarks: $A$. chenevieri has an irregular pattern of small ridges on the surface of the cyst. It was originally described from "reworked Eocene" in the Caspian Sea and was found in the upper Eocene sediments at Site 340 on the V $\phi$ ring Plateau.

\section{Archaeomonas ef. A. circuligera Rampi, 1969 \\ (Plate 2, Figure 7)}

Remarks: The archaeomonad illustrated by the SEM photograph seems to be close to $A$. circuligera as shown by an LM photograph and drawings by Rampi (1969). A. circuligera has, however, relatively smaller circular ornaments than the form illustrated here, which was found in the upper Eocene sediments at Site 340 on the V $\phi$ ring Plateau. A. circuligera was described from the upper Eocene Kreyenhagen diatomite in California.

\section{Archaeomonas deflandrei Rampi, 1948 \\ (Plate 2, Figure 6)}

Remarks: $A$. deflandrei is a small archaeomonad with a simple opening and low, but thin ridges. It was described originally from the Miocene diatomite of Sicily and illustrated by a rather schematic drawing. Similar forms are A. gracilis Tynan, 1960, which has a collar, and A. lefeburei Deflandre, 1933, which also has a collar and a simpler pattern of ridges. $A$. deflandrei occurs in the Miocene of the V $\phi$ ring Plateau.

\section{Archaeomonas cf. A. dentata Deflandre, 1932c}

(Plate 4, Figures 9, 10)

Remarks: $A$. dentata was described from the lower Eocene diatomite of Fur, Denmark, as an archaeomonad with conical spines of different length. The form illustrated here shows spines more equal in length, and occurs in the Oligocene at Site 338 on the V $\phi$ ring Plateau.

\section{Archaeomonas dubia Deflandre, 1933}

(Plate 2, Figures 8, 9; Plate 3, Figure 10)

Remarks: A. dubia, as described from the upper Eocene diatomite of Oamaru, New Zealand, is an archaeomonad with a simple collar and a large number of small spines. Such forms are common in some samples of the Miocene at Site 339 on the $V \phi$ ring Plateau and in the Miocene and Pliocene of Site 348 on the Icelandic Plateau.

\section{Archaeomonas helminthophora Deflandre, 1933}

(Plate 1, Figures 12, 16; Plate 3, Figures 23, 24)

Remarks: The SEM picture of $A$. helminthophora shows the small opening to lie on a small platform. This species was described originally from the Miocene diatomite of Maryland, USA, and was found to occur in the Miocene at Site 338 on the V $\phi$ ring Plateau.

Archaeomonas heteroptera Deflandre, 1932c

(Plate 1, Figures 17-20; Plate 3, Figures 23-26)

Remarks: A. heteroptera was described from the lower Eocene diatomite of Fur, Denmark, and was also found in the upper Eocene 
Kreyenhagen diatomite in California, and at DSDP Site 283 in the subantarctic southwest Pacific. From the Miocene of Japan, Bachmann (1964) described an A. heteroptera with a simpler collar than the one usually seen on Paleogene forms of this species. The same difference could be seen in the forms studied here, between the Eocene and Miocene specimens. The number of ridges, their height, and the size of the specimens vary greatly.

\section{Archaeomonas japonica Deflandre, 1933}

(Plate 3, Figure 9)

Remarks: $A$. japonica was originally described from the Miocene of Japan, but also occurs in the Eocene (Kreyenhagen) of California and in the Oligocene to the Miocene at DSDP Site 278 in the subantarctic southwest Pacific. On the V $\phi$ ring Plateau, it was found in the upper Eocene sediments at Site 340.

\section{Archaeomonas karinae n. sp.}

(Plate 2, Figures 15-17)

Holotype: Plate 2, Figure 15

Diagnosis: Archaeomonas, spherical with conical spines. Thin, shallow ridges radiate from the base of the spine, some connecting the spines by a ridge. The opening is small and surrounded by a simple collar.

Remarks: In similar forms, like A. longispina Rampi, 1948, there are only the ridges connecting the spines and no other ridges radiating from the spines.

Occurrence: A. karinae is rare in the late Eocene at Site 340 on the $\checkmark \phi$ ring Plateau.

\section{Archaeomonas kreyenhagenensis Rampi, 1969} (Plate 3, Figure 17)

Remarks: A. kreyenhagenensis was described from the Eocene of Kreyenhagen, California and occurs in the late Eocene at Site 340 on the V $\phi$ ring Plateau.

\section{Archaeomonas cf. A. lefeburei Deflandre, 1933}

(Plate 3, Figures 13, 14)

Remarks: A. lefeburei, as described from the Eocene diatomite from Oamaru, New Zealand, has less shallow ridges than the form illustrated here from the late Eocene of Site 340 on the V $\phi$ ring Plateau. Some of the ridges cross at right angles.

\section{Archaeomonas multipunctata Rampi, 1969}

(Plate 2, Figures 10, 13)

Remarks: Small archaeomonads with a simple opening and a large number of small conical spines are assigned to A. multipunctata, although they are smaller than the holotype of this species. A. multipunctata was originally described from the Eocene (Kreyenhagen) diatomite of California and was found in the Eocene at Site 340 and in the Oligocene at Site 338 on the V $\phi$ ring Plateau.

\section{Archaeomonas ninge n, sp.}

(Plate 1, Figures 13-15)

Holotype: Plate 1, Figure 13.

Diagnosis: Archaeomonas with wedge-formed ornamentations which are pierced by small holes. The opening is small and is not surrounded by a collar.

Remarks: A. ninae is similar to A. helminthophora, but differs from the latter by the consistent presence of small holes in the ornamentations.

Occurrence: $A$. ninae is not rare in the upper Eocene sediments at Site 340 on the V $\phi$ ring Plateau.

\section{Archaeomonas norvegiensis n. sp.}

$$
\text { (Plate 3, Figures 21, 22) }
$$

Holotype: Plate 3, Figures 21, 22.

Diagnosis: Archaeomonas with high, slender ridges which are longer than the cyst itself including the collar.

Remarks: A. norvegiensis is similar to A. heteroptera, but differs from the latter by the longer ridges.

Occurrence: $A$. norvegiensis was found only in one sample of late Eocene age at Site 340 on the V $\phi$ ring Plateau.

\section{Archaeomonas oamaruensis Deflandre, 1933}

(Plate 2, Figures 18-21; Plate 3, Figure 8)

Remarks: In $A$. oamaruensis, as described from the diatomite of late Eocene age at Oamaru, New Zealand, the collar also bears spines which are somewhat smaller than the spines on the cyst itself. Such forms were found in the Eocene at Site 340 and the Miocene at Site 338 on the V $\phi$ ring Plateau. In some specimens, low ridges connect the spines.

\section{Archaeomonas ef. A. ornata Rampi, 1969}

(Plate 1, Figure 11)

Remarks: A. ornata was described from the Eocene Kreyenhagen diatomite of California and has an ornamentation consisting of small spines surrounded by round depressions. In the specimen illustrated here, the small spines are surrounded by pentagonal and hexagonal depressions. This form was found in the Eocene at Site 339 on the V申ring Plateau.

\section{Archaeomonas ovoidea Deflandre, 1933}

(Plate 4, Figures 14, 15)

Remarks: A. ovoidea, a large and easily recognizable archaeomonad, was described from the middle Miocene diatomite of San Pedro, California and was found in the middle or late Miocene at Site 341 on the V $\phi$ ring Plateau.

\section{Archaeomonas cf. A. ovoidea Deflandre, 1933}

(Plate 4, Figures 12,13)

Remarks: The form illustrated here is similar to A. ovoidea in size and ornamentation. It has, however, an elliptical rather than an eggshaped outline and its collar bears spines, whereas $A$. ovoidea is eggshaped and has no spines on the collar. $A$. cf. ovoidea occurs in the Miocene at Site 338 on the V $\phi$ ring Plateau.

\section{Archaeomonas paucispinosa Deflandre, 1938}

(Plate 2, Figure 3; Plate 3, Figure 15)

Remarks: A. paucispinosa is a small archaeomonad with few short spines and a simple opening. It was found in the late Eocene of Site 340 on the V $\phi$ ring Plateau.

\section{Archaeomonas robusta Rampi, 1969}

(Plate 2, Figure 14)

Remarks: $A$. robusta is a relatively large form with a collar and many short, but thick, spines. It was described from the Kreyenhagen diatomite of Eocene age of California and occurs in the Eocene at Site 339 on the V $\phi$ ring Plateau.

\section{Archaeomonas semplicia Rampi, 1940}

$$
\text { (Plate 2, Figure 5) }
$$

Remarks: A. semplicia as described from the Upper Cretaceous diatomite of Moreno, USA, has a smooth surface and a slightly conical collar. It was found in the upper Eocene sediments at Site 340 on the V $\phi$ ring Plateau.

\section{Archaeomonas speciosa Deflandre, 1932c}

(Plate 4, Figure 1)

Remarks: A. speciosa from the Miocene diatomite of Maryland, shows a somewhat irregular net-like ornamentation. As in the specimen illustrated here, the meshes of the net are large. It was found also in the Miocene of Hungary and occurs in the Miocene at Site 338 on the V $\phi$ ring Plateau.

\section{Archaeomonas sphaerica Deflandre, 1932c}

(Plate 2, Figure 4)

Remarks: A. sphaerica, a relatively large form consisting of a sphere with a smooth surface and an opening without a collar, occurs in the Miocene of Site 338 on the V $\phi$ ring Plateau. It was originally described from the lower Eocene diatomite of Fur, Denmark, but has been found also in the Miocene of Hungary and Yugoslavia.

\section{Archaeomonas sphaeroidea Deflandre, 1938}

$$
\text { (Plate 3, Figure 18) }
$$

Remarks: Like A. sphaerica, A. sphaeroidea has a smooth surface and an opening without a collar. Around the opening, the sphere is 
flattened. The species was described from the upper Eocene diatomite of Oamaru, New Zealand, and was also found at DSDP Site 281 in the subantarctic southwest Pacific in upper Eocene samples. On the $\mathrm{V} \phi$ ring Plateau, it occurs in the Miocene at Site 341.

Archaeomonas striata Deflandre, 1933

(Plate 1, Figures 1-4; Plate 3, Figures 1-6)

Remarks: The holotype of $A$. striata shows five parallel ridges parallel to the plane of the opening and five parallel ridges in an angle of about $45^{\circ}$ to this plane. A. striata's holotype was illustrated by a drawing and later a photograph of it was given in Deflandre and Deflandre-Rigaud (1970), who also published SEM pictures of the species, taken from the same material as the holotype. These pictures show specimens with about 15 very thin and low ridges. The variation is not so considerable in the material from the Miocene of Site 338 and the late Eocene of Site 340 from the V $\phi$ ring Plateau as in the diatomite from Fur, Denmark, from where the holotype was described. The opening is surrounded by a low collar. The species was also found in the Miocene at DSDP Site 278 in the subantarctic southwest Pacific.

\section{Archaeomonas vermiculosa Deflandre, 1932c}

$$
\text { (Plate 1, Figure 9) }
$$

Remarks: The specimen illustrated here has a somewhat larger collar than the holotype of $A$. vermiculosa which was described from the Miocene diatomite of Maryland. It was found in the Miocene at Site 341 on the V $\phi$ ring Plateau.

\section{Archaeomonas sp. 1 \\ (Plate 3, Figure 7)}

Remarks: The form illustrated here has a simple opening and an ornamentation consisting of a pattern of hexagonal and pentagonal ridges. It occurs only in one sample of Oligocene age at Site 338 on the V $\phi$ ring Plateau.

\section{Archaeomonas sp. 2}

(Plate 3, Figure 19)

Remarks: Archaeomonas with a smooth surface and spines with parallel sides and of different length. It was found only in one sample of late Eocene age at Site 340 on the V $\phi$ ring Plateau.

Archaeomonas sp. 3

(Plate 4, Figures 11, 16)

Remarks: A large archaeomonad similar to A. ovoidea, but almost spherical and with a finer ornamentation. It occurs in the Miocene at Site 341 on the V $\phi$ ring Plateau.

\section{Genus ARCHAEOSPHAERIDIUM Deflandre, 1932a}

\section{Archaeosphaeridium cf. A. dangeardianum Deflandre, 1932c} (Plate 2, Figure 1)

Remarks: The holotype of $A$. dangeardianum, which was described from the Miocene diatomite of Maryland, shows a rough surface, a large collar, and a small opening. The specimen illustrated here has a much lower collar and has less small spines. It is closer to forms assigned to $A$. dangeardianum by Deflandre (1938) from the lower Eocene diatomite of Mors, Denmark, and occurs in the upper Eocene sediments at Site 340 on the $\mathrm{V} \phi$ ring Plateau. Forms with a smooth surface have also been attributed to $A$. dangeardianum.

\section{Archaeosphaeridium ornatum Deflandre, 1932a}

(Plate 4, Figures 17-21)

Remarks: A. ornatum is a very large archaeomonad described from the Miocene diatomite of New Jersey. It has a somewhat rough surface and short, wedge-shaped spines. The collar is large with a large opening. It was here found in the Miocene at Site 341 on the V $\phi$ ring Plateau. It seems to be a typical Miocene species.

\section{Archaeosphaeridium cf. A. pachyceros Deflandre, 1933}

(Plate 2, Figure 2)

Remarks: $A$. pachyceros is a large archaeomonad with long conical spines and was described from the Miocene diatomite of New Jersey and also found in the Miocene of Japan. The form illustrated here, on the contrary, is very small and occurs only in the late Eocene at Site 340 on the V $\phi$ ring Plateau.

\section{Genus LITHARCHAEOCYSTIS Deflandre, 1932b}

\section{Litharchaeocystis costata Deflandre, 1932b}

(Plate 3, Figure 37)

Remarks: The cyst of $L$. costata is decorated with low longitudinal ridges extending into spines below the cyst, thus forming "legs" to the cyst which has an elliptical outline. It was described from the Paleocene-Eocene diatomite of Kusnetzk, USSR. It was here found in the late Eocene of Site 340 on the V $\phi$ ring Plateau.

\section{Litharchaeocystis glabra Rampi, 1948}

(Plate 3, Figure 27)

Remarks: L. glabra has a smooth surface and only few, small spines around the bottom of the bottle-shaped form. It was originally described from the upper Eocene diatomite of Oamaru, New Zealand, and here occurs in the upper Eocene at Site 340 on the V $\phi$ ring Plateau.

\section{Litharchaeocystis oamaruensis Deflandre, 1938}

(Plate 3, Figures 28, 29, 32)

Remarks: L. oamaruensis from the upper Eocene diatomite of Oamaru, New Zealand, is oval to bottle-shaped and has longitudinally oriented ridges extending into prominent spines at the bottom of the form. It was found in the upper Eocene at Site 340 on the V $\phi$ ring Plateau.

\section{Litharchaeocystis talwanii n. sp.}

(Plate 3, Figures 34-36)

Holotype: Plate 3, Figures 35, 36.

Diagnosis: A bottle-shaped form of Litharchaeocystis with prominent longitudinal ridges extending into vertical spines.

Remarks: $L$. talwanii differs from the other species of Litharchaeocystis by the very prominent ridges and the vertical spines. L. glabra has a smooth surface and the ridges on all other thus far described species are finer and lower, and the spines usually not vertical.

Occurrence: L. talwanii is not rare in the late Eocene at Site 340 on the V $\phi$ ring Plateau.

Litharchaeocystis udintsevii n. sp.

(Plate 3, Figures 30, 31, 33)

Holotype: Plate 3, Figures 30, 31.

Diagnosis: A bottle to cone shaped form of Litharchaeocystis with low, fine ridges extending into spines around the flat bottom of the form.

Remarks: L. udintsevii is broader than all other species of this genus.

Occurrence: $L$. udintsevii is not rare in the late Eocene at Sites 338 and 340 on the V $\phi$ ring Plateau.

\section{Genus LITHEUSPHAERELLA Deflandre, 1932a}

Litheusphaerella spectabilis Deflandre, 1932a

(Plate 2, Figures 11, 12)

Remarks: The illustrated specimens of $L$. spectabilis show two different states of preservation of this species. It was found in the upper Eocene sediments at Site 340 on the V $\phi$ ring Plateau and was originally described from the lower Eocene diatomite of Fur, Denmark. It has also been found in the Eocene diatomite of Isenski, USSR, and the Late Cretaceous at DSDP Site 275 in the subantarctic southwest Pacific.

\section{Litheusphaerella sp. 1}

(Plate 4, Figures 6-8)

Remarks: The specimens illustrated here seem to belong to Litheusphaerella, but they have more and smaller T-shaped spines than the species of this genus thus far described. They are the first Litheusphaerella reported from the Neogene and occur in the Miocene at Sites 338 and 341 on the V $\phi$ ring Plateau. 


\section{Genus PARARCHAEOMONAS Deflandre, 1932c}

Pararchaeomonas challengeri n. sp. (Plate 3, Figure 16)

Holotype: Plate 3, Figure 16.

Diagnosis: Pararchaeomonas, almost spherical and with a "turtleneck" around the opening. The surface is smooth, or covered with tiny spines.

Remarks: $P$. challengeri differs from the other species of the genus by its turtleneck-shaped collar around the opening. P. colligera Deflandre, 1932d, has a holotype with a simple collar, and a paratype which shows a turtleneck similar to the one of $P$. challengeri.

Occurrence: $P$. challengeri was only found in the late Eocene at Site 340 on the V $\phi$ ring Plateau.

\section{EBRIDIANS}

Ebridians are marine, planktonic organisms secreting silica. They are most commonly found in cold or temperate waters. Their fossil record goes back to the Paleocene, but most genera and species are recorded from the Eocene and Miocene.

\section{Late Eocene}

Relatively rich ebridian assemblages were found in some of the samples from the siliceous upper Eocene sequences at Sites 339 and 340. Preservation varies from very poor to moderate. The assemblages include many of the forms found in the subantarctic southwest Pacific (Perch-Nielsen, 1975), but lack completely Micromarsupium and Craniopsis. On the other hand, Ammodochium complexum, A. novum, and Parebriopsis symmetrica are new species from the Eocene of the Norwegian Sea.

\section{Oligocene}

Ebridians are only present in one sample of definite (middle) Oligocene age (338-21-1, $145 \mathrm{~cm})$. Hermesinum geminum, one of the few species also found in the Oligocene (and late Eocene) of DSDP Site 280, south of Tasmania, is also present.

\section{Miocene}

Miocene ebridian assemblages were found at Sites $338,341,342$, and 348 . They are poorer than those of the late Eocene, but ebridians are more common and diverse than in the Oligocene. At Site 346, no ebridians were found despite the abundance of other siliceous microfossils. The Miocene assemblage includes Parathranium, a genus which was not represented in the Miocene of the subantarctic southwest Pacific, whereas Ammodochium rectangulare and Ebriopsis crenulata are relatively common in both areas.

\section{Pliocene-Pleistocene}

Pliocene-Pleistocene siliceous sediments were recovered at Site 348. E. crenulata and Pseudammodochium $\mathrm{cf}$. $P$. dictyoides are very rare in Cores $348-5$ and 348-6.

\section{SYSTEMATIC PALEONTOLOGY}

In the following, an inventory of the ebridians found in samples from Leg 38 is given. No attempt was made to present the synonymy for each species or to discuss its architecture or history. The morphologic terms used are those commonly employed and summarized by Deflandre (1951).
The holotypes of Ammodochium complexum n. sp. and Parebriopsis symmetrica n. sp. are designed in Sample Vema $43 / 28-220 \mathrm{~cm}$, a piston core from the $\mathrm{V} \phi$ ring Plateau, because of the better preservation there than in the Leg 38 material where these species also occur. The age assigned to the Vema sample by diatoms and silicoflagellates was (?) late Eocene (Bjфrklund and Kellogg, 1972), the same age as the samples in which they occur in Leg 38 material.

\section{Genus AMMODOCHIUM Hovasse, 1932d}

\section{Ammodochium complexum Dumitrica and Perch-Nielsen, n. sp.} (Plate 8, Figures 15, 16; Plate 10, Figure 11)

Holotype: Plate 10, Figure 11.

Description: Skeleton inflate, with one end-supposedly the nuclear one-wider than the opposite end. Three equal proclades and three opisthoclades approximately similar to the proclades. They all have, commonly, three large pores, one oriented towards the triode, two to the nuclear and the antapical ring, respectively. Thus, both rings are generally surrounded by six pores. The nuclear ring is larger than the antapical one. The proclades and opisthoclades are connected by an $\mathrm{H}$-shaped mesoclade which gives rise to three pores: a lateral pore between the mesoclade and the proximal ends of the proclade and the opisthoclade, and two outer pores which have their distal wall in common with that of the unpaired pore of the proclade and the opisthoclade. The scaffolding of the skeleton seems to suggest that the three actines of the triode fork in a vertical plane, giving rise to the proclades and opisthoclades, which fork at their turn in a perpendicular plane, each branch being connected with the nearest branch of the adjoining pro- or opisthoclade.

A superficial ornamentation is visible on the relatively wellpreserved specimen Plate 8, Figure 16, and consists of a network of crests. A small hole occurs at the meeting points of the crests. This is in contrast to the occurrence of knobs at meeting points of crests in the ornamentation found on silicoflagellates. The internal parts of the skeleton show no ornamentation.

Sample: Vema $43 / 28-220 \mathrm{~cm}$.

Remarks: This species is the most complex species of the genus Ammodochium so far known. It resembles A. speciosum Deflandre, from which it differs by a greater complexity. It differs from $A$. novum by the lack of mesoclades in the latter.

Occurrence: A. complexum is rare in Samples Vema $43 / 28-220 \mathrm{~cm}$ and $330 \mathrm{~cm}$ (late Eocene?) and was found in the late Eocene and early Oligocene at Sites 340 and 338 on the $\mathrm{V} \phi$ ring Plateau.

\section{Ammodochium novum n. sp. \\ (Plate 8, Figures 13, 14)}

Holotype: Plate 8, Figure 14.

Description: Skeleton with one end, supposedly the nuclear one, wider than the opposite one. The three proclades are similar to the three opisthoclades and each bear three large, usually round pores. Two are oriented towards the nuclear and the antapical ring, the third towards the triode. An extra pore of the same form and size lies between the two pores oriented towards the triode.

A superficial ornamentation is visible on well-preserved specimens such as those illustrated on Plate 8 and consists of a network of crests. Where the crests meet, they form a short spine with a small hole in the middle. The internal parts of the skeleton show no ornamentation.

Sample: DSDP $339-11-1,100 \mathrm{~cm}$.

Remarks: This species is very similar to $A$. complexum, but differs from it by the lack of mesoclades and the presence of an extra pore between the opisthoclade and the proclade.

Occurrence: A. novum was found in the late Eocene at Site 339 on the V $\phi$ ring Plateau, where it is rare.

\section{Ammodochium cf. A. prismaticum Hovasse, 1932a} (Plate 8, Figure 20)

Remarks: A. prismaticum was originally described from the Paleocene/Eocene from Denmark. In the specimen illustrated here, the apical structure is smaller than the central tripod, while it is the other way around in the A. prismaticum. Also, the apical structure in the double skeleton shown on Plate 8 is nearly round, whereas it is triangular in A. prismaticum from Denmark and rhombohedrical in $A$. prismaticum paradoxum Hovasse from the upper Eocene of New Zealand. 
Occurrence: $A$. cf. A prismaticum was only found in Cores $338-8$ to 338-18 of (?) late Oligocene to (?) late Miocene age.

\section{Ammodochium rectangulare (Schulz) Deflandre, 1933}

(Plate 8, Figures 17-19)

Remarks and Occurrence: $A$. rectangulare occurs from the late Eocene through the Miocene in many samples from the $\mathrm{V} \phi$ ring Plateau sites. Well-preserved specimens show an ornamentation consisting of knobs connected by crests. The internal parts of the skeleton show no ornamentation.

\section{Genus EBRIOPSIS Hovasse, 1932a}

\section{Ebriopsis cornuta Dumitrica and Perch-Nielsen, 1975}

(Plate 9, Figures 1-5; Plate 10, Figure 13)

Remarks: E. cornuta was originally described from a Vema sample $(43 / 28-520 \mathrm{~cm})$ from the $V \phi$ ring Plateau and was also found to occur very rarely in the Eocene at Site 277 in the subantarctic southwest Pacific. On well-preserved specimens, an ornamentation consisting of ridges can be observed on the external part of the skeleton.

Occurrence: Besides the occurrence at Site 277 in the subantarctic southwest Pacific and the Vema sample from the V $\phi$ ring Plateau, $E$. cornuta was also found at Sites 338 and 340 in the late Eocene, where it is not rare.

\section{Ebriopsis crenulata Hovasse, 1932b}

(Plate 9, Figures 6-8)

Remarks and Occurrence: $E$. crenulata occurs in the late Eocene at Sites 338 and 340 . It was originally described from the upper Eocene of New Zealand and was found, more or less consistently, in the late Eocene and in the Oligocene of Sites 277, 280, 281, and 283 in the subantarctic southwest Pacific. The surface ornamentation also consists of crests forming small holes at their meeting points.

\section{Genus FALSEBRIA Deflandre, 1951}

"Falsebria" sp.

(Plate 8, Figures 9-11)

Remarks and Occurrence: Deflandre (1951) created the genus Falsebria for forms that differed from Ebriopsis only by the absence of synclades and sometimes reduced or absent opisthoclades. No attempt was made here to assign the specimens shown on Plate 8 to Deflandre's species of Falsebria, since these forms are here considered to be initial stages of other ebridians rather than belonging to a genus of their own. "Falsebria" occur in many samples of Eocene to Miocene age, which include other ebridians.

\section{Genus HAPLOHERMESINUM Hovasse, 1943}

\section{Haplohermesinum simplex (Schulz) Hovasse, 1943} (Plate 9, Figures 10-19, 20?, 21?)

Remarks and Occurrence: The ornamentation on the outer side of the skeleton consists of ridges showing holes at their meeting points in well, but not excellently preserved specimens. The inner part of the skeleton shows no ornamentation. $H$. simplex occurs in the late Eocene or Oligocene to Miocene at Site 338.

\section{Genus HERMESINOPSIS Deflandre, 1934}

\section{Hermesinopsis caulleryi Deflandre, 1934}

$$
\text { (Plate 10, Figures 1-8) }
$$

Remarks and Occurrence: More or less well-preserved specimens of $H$. caulleryi show a fine ornamentation consisting of crests which show small holes at their meeting points on the outer side of the skeleton. $H$. caulleryi was originally described from the Eocene of Barbados and was found in the late Eocene to Miocene of Sites 338 and 339.

\section{Genus HERMESINUM Zacharias, 1906}

Hermesinum geminum Dumitrica and Perch-Nielsen, 1975 (Plate 10, Figure 12)

Remarks and Occurrence: Only one broken specimen of $H$. geminum was found in the middle Oligocene at Site 338. H. geminum was described from the late Eocene and Oligocene at Site 280 south of Tasmania, and was also found in Sample Vema $43 / 28-520 \mathrm{~cm}$ on the $\mathrm{V} \phi$ ring Plateau. Also the specimen found in Sample 338-21-1, $145 \mathrm{~cm}$ is a double skeleton, as all the other specimens thus far reported of this species.

\section{Genus PARATHRANIUM Hovasse, 1932d}

Parathranium intermedium Hovasse, 1932d

(Plate 7, Figures 1-16, Plate 10, Figures 15-17)

Remarks and Occurrence: Ling and McPherson (1974) have recently commented on the status of the genus Parathranium versus Dicladia. The specimens illustrated on Plate 7 have opisthoclades of varying length, mainly due to breaking off of the slender tips of the opisthoclades. Some specimens, like those shown on Plate 7 Figures 10 and 11 , have two spines on the synclades like those described for Parathranium bispinum Deflandre, 1951, whereas spines are less prominent in others. Double skeletons occur frequently in most samples where $P$. intermedium was found: in the late Oligocene or early Miocene to early or middle Miocene at Site 338, and in the mid or late Miocene at Site 341. The ornamentation of the outer part of the skeleton consists of crests forming a network with short spines at the meeting points of the crests.

\section{Genus PAREBRIA Hovasse, 1932c}

\section{Parebria valida Deflandre, 1934 (Plate 9, Figure 9)}

Remarks and Occurrence: $P$. valida was originally described from the late Paleocene/early Eocene of Denmark. The Danish specimens are somewhat shorter than the specimen illustrated on Plate 9, which was found in the Eocene at Site 340.

\section{Genus PAREBRIOPSIS Hovasse, 1932d}

\section{Parebriopsis symmetrica Dumitrica and Perch-Nielsen n. sp.}

(Plate 10, Figures 10,14)

Description: Convex, disc-shaped skeleton consisting of two equal "triodes" opposite one another by their concavity and symmetrically superposed as against the equatorial plane. The two "triodes" are connected to one another by the three branches of each arm, two of which are parallel to the surface of the disc, and a third one pillarshaped and perpendicular to the equatorial plane. All these skeletal elements are inscribed in an equatorial ring consisting of three synclades and three mesoclades. The skeleton thus has six large windows, three on each side of the disc, which are limited by the three arms of the "triodes" and the synclades of the equatorial ring, and six small windows, one at each distal end of the arms, situated between the two external branches of the arms and the short mesoclades lying in the equatorial ring. There are also other six inner windows, two for each pair of arms, situated between the inner pillars and the two external branches of the arms.

Double skeletons were also found (Plate 10, Figure 10), but are rare. A superficial ornamentation is barely visible on the somewhat better preserved specimens. It consists of a network of crests with small holes forming where the crests meet. This pattern is observed in many ebridians on the outer side of their skeletons.

Holotype: Plate 10, Figure 10.

Sample: Vema $43 / 28-220 \mathrm{~cm}$, ?late Eocene V $\phi$ ring Plateau, Norwegian Sea.

Remarks: Parebriopsis is the only genus to which this species could be assigned. $P$. symmetrica shows the following morphological resemblances with $P$. fallax Hovasse, the generotype of Parebriopsis and thus far the only species of the genus: skeleton consisting of two opposite "triodes"; connection between these "triodes" made by short pillars; and bifurcation of the arms of the "triodes" and small windows between these distal branches. $P$. symmetrica differs from $P$. fallax by: (1) the very regular skeleton; (2) the superimposed position of the two opposite "triodes," while they are turned with about $60^{\circ}$ in $P$. fallax; (3) the presence of the three connecting pillars, while there are only two in P. fallax; (4) the number of the small windows at the distal ends of all arms, while there are only two small windows, one at the distal ends of al, the other of sa12, and possibly other two at the distal ends of a 3 and sa23 in $P$. fallax.

By its morphology, $P$. symmetrica has the same relation to $P$. fallax as Ebriopsis crenulata to E. valida. A nomenclature problem arises 
concerning the various elements of the skeleton of $P$. symmetrica. Deflandre (1951, fig. 80-87) interpreted $P$. fallax as consisting of an initial triaene, with the actine a 2 missing, so that the initial skeleton is a false triode. One arm of this "triode" would be the rhabde $r$, the other two the actines al and a3. The opposite "triode" would consist of the opisthoclade 02 , and the anterior synclades sa23 and sa 12 . While it is easy to make these distinctions in $P$. fallax, it is very difficult in $P$. symmetrica because of its perfect triradial symmetry. It could, however, be supposed, that the "triode" with the tricostate arms could be a remain of the initial triaene. One arm of this "triode" would represent the rhabde, the other two the actines al and a3. but due to the perfect symmetry it is not possible to establish which of the elements should be assigned as rhabde and which as actines.

Occurrence: $P$. symmetrica is not rare in Samples Vema 43/28-177 $\mathrm{cm}, 220 \mathrm{~cm}$, and $520 \mathrm{~cm}$, and was also found very rare in the late Eocene to early Oligocene Sample $339-11-1,100 \mathrm{~cm}$.

\section{Genus PSEUDAMMODOCHIUM Hovasse, 1932d}

Pseudammodochium sp.

(Plate 6, Figures 17-20)

Remarks and Occurrence: $P$. dictyoides was described from the Eocene of New Zealand, as was $P$. sphaericum, while $P$. robustum was described from the Miocene of Japan. The specimens illustrated on Plate 6 have more and smaller pores than any previously described species of Pseudammodochium. They occur in the Eocene at Sites 338 and 340 and in the Miocene at Site 339.

\section{ENDOSKELETAL DINOFLAGELLATES}

Endoskeletal dinoflagellates were recorded from DSDP Leg 21 (Dumitrica, 1973) and Leg 29 (PerchNielsen, 1975). Besides few of the previously described species, one new species, Foliactiniscus atlanticus, was found in the Miocene at Sites 338 and 342. The assemblages are essentially similar to those found on Leg 29 , with the diversity only slightly higher in the Neogene of the Norwegian Sea than in the subantarctic southwest Pacific, but considerably lower than on Leg 21 in lower southern latitudes.

\section{SYSTEMATIC PALEONTOLOGY}

Dumitrica (1973) has discussed the systematical considerations relating to the assignment of the genera found here to the family $\mathrm{AC}$ tiniscidae.

\section{Family ACTINISCIDAE Kutzing}

Genus ACTINISCUS Ehrenberg, 1854

\section{Actiniscus elongatus Dumitrica, 1968}

(Plate 5, Figures 13, 14)

Remarks and Occurrence: A. elongatus shows an ornamentation consisting of crests oriented perpendicular to the elongation of the body. It is rare in the Miocene at Site 341.

\section{Actiniscus pentasterias Ehrenberg, 1840}

(Plate 5, Figures 1-7, 9-11; Plate 6, Figures 9, 13-16)

Remarks and Occurrence: A. pentasterias is found with five to seven or eight arms and a high variety of ornamentation. Also the height and the length of the arms differ considerably. A. pentasterias was found consistently in the Oligocene and Miocene at Site 338, and in the Miocene at Site 341.

Abnormal forms of $A$. pentasterias show two alveolar structures (Plate 6, Figure 13) and/or a bifurcation at the end of one arm (Plate 6, Figures 13-16). The latter forms occur only in the early to middle Miocene at Site 338.

\section{Actiniscus tetrasterias Ehrenberg, 1854}

(Plate 5, Figures 17-19)

Remarks and Occurrence: The ornamentation on A. tetrasterias is not so well developed as on A. pentasterias. A. tetrasterias is rare in the Miocene at Sites 338 and 341.
Actiniscus sp.

(Plate 5, Figures $8,12,15$ )

Remarks and Occurrence: Actiniscus sp. resembles A. pentasterias, but has longer arms and more pronounced spines on the apical part without reaching the extreme forms of $A$. radicula Dumitrica (1973). The median crest on the arm is also armed with few, but prominent spines. Actiniscus sp. is rare in the Miocene at Sites 338 and 341.

\section{Genus CALCIPEDINIUM Dumitrica, 1973}

Calcipedinium quadripes Dumitrica, 1973 (Plate 5, Figure 16)

Remarks and Occurrence: Dumitrica (1973) described C. quadripes as a "spicule with star-shaped basal plate consisting of four, exceptionally three or five, three-bladed arms." The few specimens found in the Miocene at Site 338 show five arms. C. quadripes was described originally from the middle Miocene of Rumania.

\section{Genus CARDUIFOLIA Hovasse, 1932d}

\section{Carduifolia gracilis Hovasse, $1932 \mathrm{~d}$} (Plate 5, Figure 20)

Remarks and Occurrence: Specimens of $C$. gracilis found in the material studied here all only show small spines on two of the three crests of the arms. C. gracilis was found in small numbers in Eocene to Miocene samples containing siliceous microfossils.

Genus FOLIACTINISCUS Dumitrica, 1973

\section{Foliactiniscus atlanticus n. sp.}

(Plate 6, Figures 1-8)

Holotype: Plate 6, Figure 6.

Sample: DSDP $338-18-1,140 \mathrm{~cm}$.

Description: Siliceous skeleton with usually six tricostate arms. The central plate shows three or more alveoli. The arms bear no ornaments and are usually paired.

Remarks: $F$. atlanticus differs from other species in this genus by the paired arms and the high number of alveoli on the central plate.

Occurrence: $F$. atlanticus occurs in the Miocene of Site 338 .

\section{Foliactiniscus folia (Hovasse) Dumitrica, 1973}

$$
\text { (Plate 6, Figures 10-12) }
$$

Remarks and Occurrence: A tendency of the crests of the arms to form an alveola could be observed on some specimens from the Miocene of Site 338. Typical for this species is also the ornamentation of the arms which consists of crests oriented perpendicular to the main crest along the arm.

\section{Siliceous dinoflagellate? \\ (Plate 10, Figures 18, 19)}

Remarks: In the late Eocene Sample $340-2-1,85 \mathrm{~cm}$ and in late Eocene samples from Vema $43 / 28$ from the V $\phi$ ring Plateau, few specimens of siliceous forms similar to usually organic-walled dinoflagellates were found.

\section{OTHER SILICEOUS MICROFOSSILS}

Some siliceous microfossils which traditionally are treated together with silicoflagellates or the groups treated here are included in this report: Clathropyxidella similis and Pseudorocella barbadiensis.

\section{Genus CLATHROPYXIDELLA Deflandre, 1938}

\section{Clathropyxidella similis Deflandre, 1938}

$$
\text { (Plate 7, Figures 17, 18) }
$$

Remarks and Occurrence: C. similis was originally described from the Eocene of Barbados. The forms found in the Eocene at Site 340 have usually the same number of windows and the same size as those illustrated by Deflandre (1938). Unlike on silicoflagellates or ebridians, there is no ornamentation observable on the skeleton. The basal ring is doubled by the frame of the vertical windows. $C$. similis was found only in the Eocene at Site 340. 
Genus PSEUDOROCELLA Deflandre, 1938

Pseudorocella barbadiensis Deflandre, 1938

(Plate 7, Figures 19, 20)

Remarks and Occurrence: $P$. barbadiensis includes a variety of simple siliceous forms with a round to more or less elliptical outline and a varying number of windows of different form and size. It was originally described from the Eocene of Barbados and was here found in the late Eocene to early Oligocene at Site 339. On Plate 7, the two sides are shown: one has a smooth surface, the other shows a rim around the smooth center of the body

\section{ACKNOWLEDGMENTS}

Above all, I would like to thank the Leg 38 shipboard party for sampling yet another set of samples for a special investigation. Dr. P. Dumitrica, Bukarest, has described two of the new ebridians. H. Franz, Zürich, has assisted in my work at the SEM of the Federal Technical Institute of Technology, and I. Nyegaard, Copenhagen, prepared the photographs and made up most plates.

\section{REFERENCES}

Bachmann, A., 1964. Part II. Silicoflagellidae und Archaeomonadaceae. In Ichikawa, W. et al., (Eds.), Fossil diatoms, pollen grains and spores, silicoflagellates and archaeomonads in the Miocene Hojuji diatomaceous mudstone, Noto Peninsula, Central Japan: Kanazawa Univ., Sci. Rept., v. 9, p. 87-118.

Bjфrklund, K.R. and Kellogg, D.E., 1972. Five new Eocene radiolarian species from the Norwegian Sea: Micropaleontology, v. 18, p. 386-396.

Cornell, W.C., 1970. The Chrysomonad cyst-families Chrysostomataceae and Archaeomonadaceae: Their status in paleontology: North Am. Paleont. Conv. Proc. Sept. 1969. Part G, p. 958-965.

Deflandre, G., 1932a. Archaeomonadaceae, une famille nouvelle de Protistes fossiles à loge siliceux: C.R. Acad. Sci., Paris, v. 194, p. 1859-1861.

1932b. Litharchaeocystis costata nov. gen. nov. spec., Chrysophycée marine fossile. Remarques sur les Chrysostomatacées. C.R. Acad. Sci., Paris, v. 194, p. $1273-1275$.

1932c. Note sur les Archaeomonadacées: Soc. Bot. France Bull., v. 79, p. 346-355.

1932d. Remarques sur quelques ébriacées: Soc. Zool. France Bull., v. 57, p. 302-315.

1932e. Sur quelques Protistes siliceux d'un sondage de la Mer Caspienne: Soc. France Micropal., Paris, Bull., v. 1, p. 1-4.

1933. Seconde note sur les Archaeomonadacées: Soc. Bot. France Bull., v. 80, p. 79-90.

, 1934. Nomenclature du squelette des Ebriacées et description de quelques formes nouvelles: Ann. Protist., v. 4 , p. $75-96$.

1938. Troisième note sur les Archaeomonadaceae: Soc. France Micropal. Bull., v. 7, p. 73-88.
1951. Recherches sur les ebriédiens, paléobiologie, evolution, systématique: Biol. France Belg. Bull., v. 85, p. 1-84.

Deflandre, G. and Deflandre-Rigaud, M., 1970. Nannofossiles siliceux I, Archaeomonadaceae: Fichier Micropaléontologique Général, Ed: Centre Nat. Rec. Sci., Paris, v. 19 , p. 4173-4400.

Dumitrica, P., 1968. Consideratii Micropaleontologice asupra orizontuli argilas cu Radiolariadin Tortonianul Regiunii Carpatice: Stud. si Cerc. Geogr. Geof. Geol., v. 13, p. 227-241.

1973. Cenozoic endoskeletal dinoflagellates in Southwestern Pacific sediments cored during Leg 21 of the DSDP. In Burns, R.E., Andrews, J.E., et al., Initial Reports of the Deep Sea Drilling Project, Volume 21: Washington (U.S. Government Printing Office), p. 819 835.

Hovasse, R., 1932a. Note préliminaire sur les Ebriacées: Soc. Zool. France Bull., v. 57, p. 118-131.

1932b. Seconde note sur les Ebriacées: Soc. Zool. France Bull., v. 57, p. 278-283.

1932c. Le stade Podamphorea et les Ebriacées: C.R. Acad. Sci., Paris, v. 195, p. 676-677.

1932d. Troisième note sur les Ebriacées: Soc. Zool. France Bull., v. 57, p. 457-476.

1943. Nouvelles recherches sur les flagellés à squelette siliceux: Ebriidés et silicoflagellés fossiles de la diatomite de Saint-Laurent-La-Vernède (Gard): Bio. France Belgique Bull., v. 77, p. 285-294.

Ling, H.Y., 1973. Silicoflagellates and ebridians from Leg 19. In Creager, J.S., Scholl, D.W., et al., Initial Reports of the Deep Sea Drilling Project, Volume 19: Washington (U.S. Government Printing Office), p. 751-775.

Ling, H.Y. and McPherson, ., 1974. Surface microstructure of selected silicoflagellates: Micropaleontology, v. 19, p. 475-480.

Perch-Nielsen, K., 1975. Late Cretaceous to Pleistocene Archaeomonads, ebridians, endoskeletal dinoflagellates, and other siliceous microfossils from the subantarctic southwest Pacific, DSDP, Leg 29. In Kennett, J.P., Houtz, R.E., et al., Initial Reports of the Deep Sea Drilling Project, Volume 29: Washington (U.S. Government Printing Office), p. 873-884.

Rampi, L., 1940. Archaeomonadacee del Cretaceo Americano: Atti Soc. Ital. Sci. Nat., v. 79, p. 60-68.

1948. Su alcune Archaeomonadacee (Crisomonadine fossili marine) nuove od interessanti: Atti Soc. Ital. Sci. Nat., v. 87, p. 185-188.

1969. Archaeomonadacées de la Diatomite Eocène de Kreyenhagen, Californie: Cahiers Micropaléontol., ser. I (Arch. Orig. Centre Docum. C.N. R.S. 461), p. 1-11.

Tynan, E.J., 1960. The Archaeomonadaceae of the Calvert formation (Miocene) of Maryland: Micropaleontology, v. 6, p. 33-39.

1971. Geologic occurrence of the Archaeomonads. In Farinacci, A. (Ed.), Plankt. Conf. Second Rome, 1970 Proc.: Roma (Tecnoscienza), p. 1225-1230. 


\section{PLATE 1}

Figures 1-4 Archaeomonas striata Deflandre; Sample 340-9-4, $100 \mathrm{~cm}$; magnification $5000 \times$.

Figures 5-8, 10 Archaeomonas areolata Deflandre; Sample 338-11$1,130 \mathrm{~cm}$ and Sample 338-8-4, $120 \mathrm{~cm}$ (fig. 5); magnification $5000 \times$.

Figure 9 Archaeomonas vermiculosa Deflandre; Sample 34134-3, $101 \mathrm{~cm}$; magnification $5000 \times$.

Figure 11 Archaeomonas cf. A. ornata Rampi; Sample 339$11-1,100 \mathrm{~cm}$; magnification $5000 \times$.

Figures 12,16 Archaeomonas helminthophora Deflandre; Samples $338-11-1,130 \mathrm{~cm}$ and $338-14-1,100 \mathrm{~cm}$; magnification $5000 \times$ and $4500 \times$.

Figures 13-15 Archaeomonas ninae n. sp.; Samples 340-10-4, 70 $\mathrm{cm}$ (fig. 13) and 340-9-4, $100 \mathrm{~cm}$; magnification $4000 \times, 3700 \times$, and $5000 \times$. (Fig. 13 is the holotype.)

Figures 17-20 Archaeomonas heteroptera Deflandre; Samples $340-9-4,100 \mathrm{~cm} ; 339-11-1,100 \mathrm{~cm} ; 340-2-1,85 \mathrm{~cm}$; and $340-9-4.100 \mathrm{~cm}$. 
PLATE 1
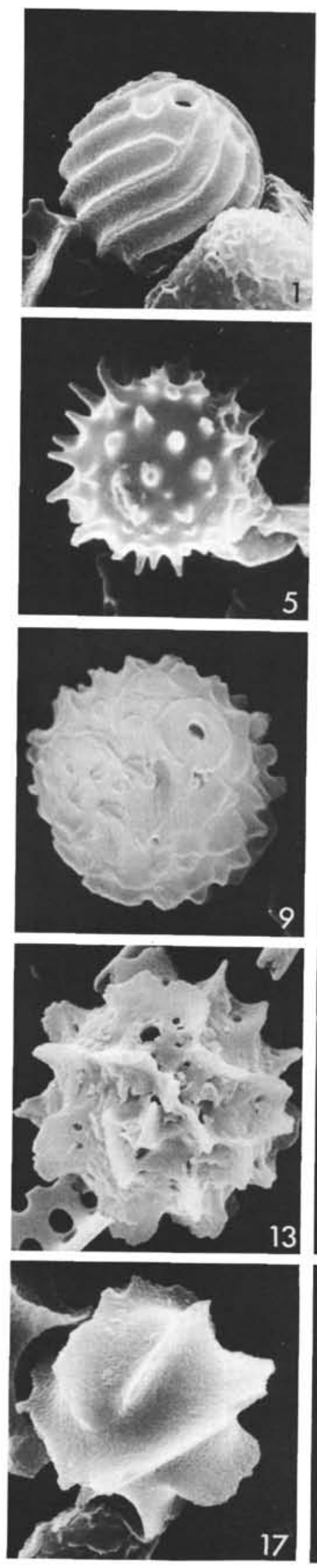
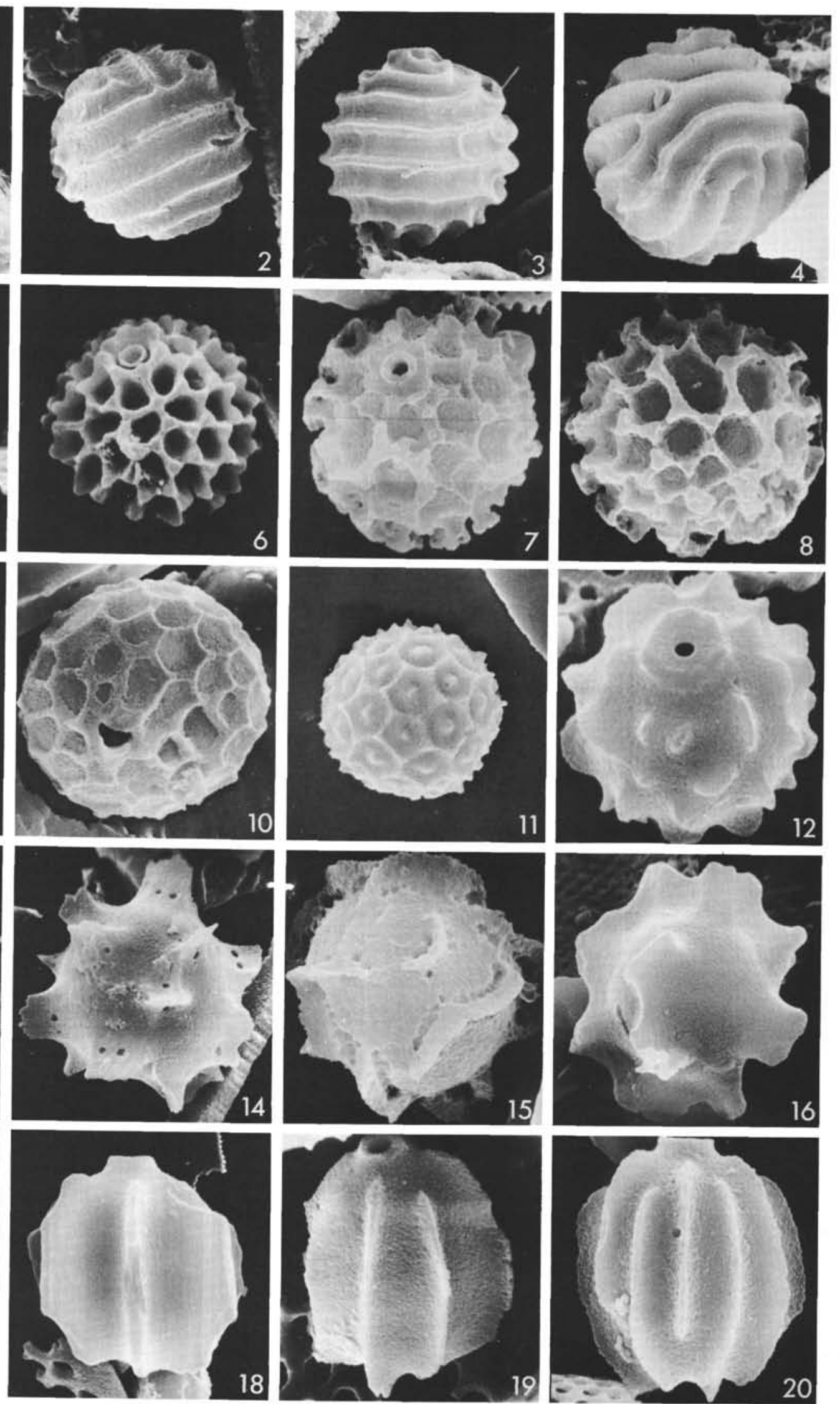
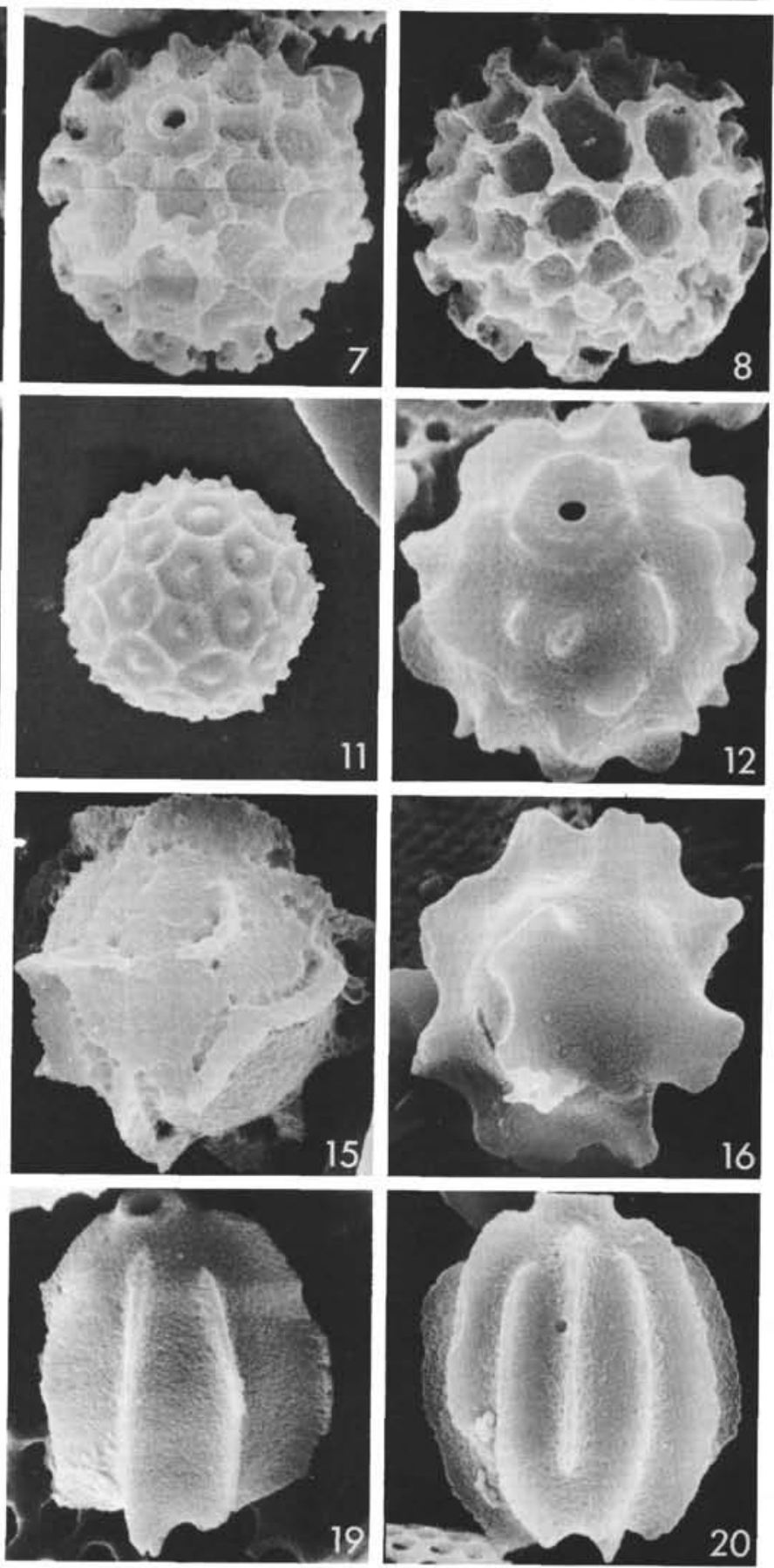


\section{PLATE 2}

Figure 1 Archaeosphaeridium $\mathrm{cf}$. A. dangeardianum Deflandre; Sample 340-9-4, $100 \mathrm{~cm}$; magnification $3000 \times$.

Figure 2 Archaeosphaeridium cf. A. pachyceros Deflandre; Sample 340-10-4, $70 \mathrm{~cm}$; magnification 5000X.

Figure 3 Archaeomonas paucispinosa Deflandre; Sample 340-11-4, $100 \mathrm{~cm}$; magnification $5000 \times$.

Figure 4 Archaeomonas sphaerica Deflandre; Sample 338$11-1,130 \mathrm{~cm}$; magnification $3000 \times$

Figure 5 Archaeomonas semplicia Rampi; Sample 340-9-4, $100 \mathrm{~cm}$; magnification $5000 \times$.

Figure 6 Archaeomonas deflandrei Rampi; Sample 339-11-1, $100 \mathrm{~cm}$; magnification $5000 \times$.

Figure 7 Archaeomonas cf. A. circuligera Rampi; Sample $340-9-4,100 \mathrm{~cm}$; magnification 5000X.

Figures 8,9 Archaeomonas dubia Deflandre; Sample 339-11-1, $100 \mathrm{~cm}$; magnification $5000 \times$ and $3500 \times$.

Figures 10, 13 Archaeomonas multipunctata Rampi; Samples 338$19-4,110 \mathrm{~cm}$ and $340-4-4,50 \mathrm{~cm}$; magnification $5000 \times$.

Figures 11,12 Litheusphaerella spectabilis Deflandre; Sample $340-2-1,85 \mathrm{~cm}$; magnification $5000 \times$.

Figure 14 Archaeomonas robusta Rampi; Sample 339-11-1, $100 \mathrm{~cm}$; magnification $4500 \times$.

Figures 15-17 Archaeomonas karinae n. sp.; Samples 340-4-4, 50 $\mathrm{cm}$ (fig. 15, holotype) and 340-2-1, $85 \mathrm{~cm}$; magnification $5000 \times$.

Figures 18-21 Archaeomonas oamaruensis Deflandre; Samples $340-9-4,100 \mathrm{~cm}$ (fig. 18, 19); 340-10-4, $70 \mathrm{~cm}$; and $338-8-4,120 \mathrm{~cm}$; magnification $5000 \times$ and $4000 \times$ (fig. 20). 
PLATE 2
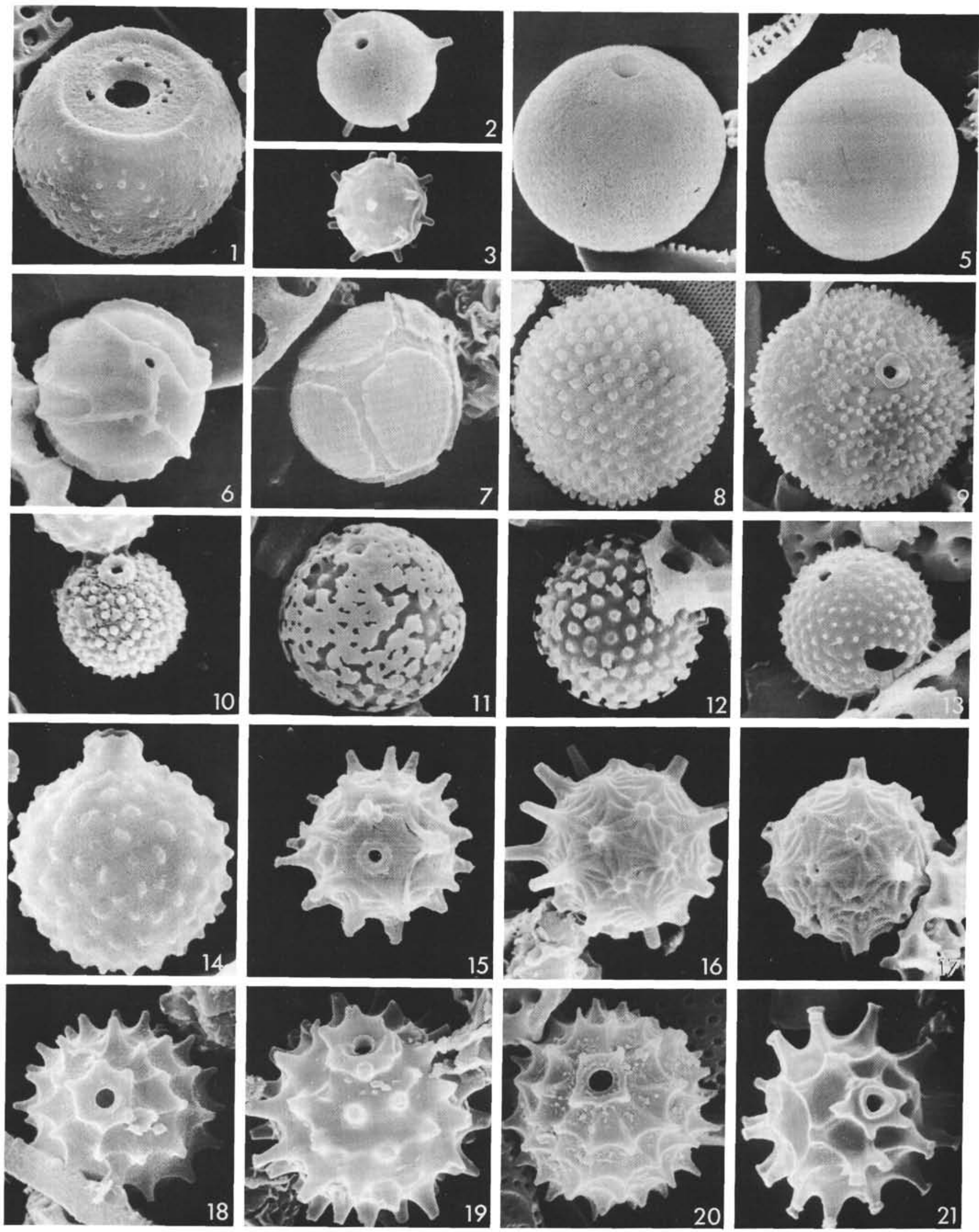
PLATE 3

Magnification (LM photographs) $2000 \times$.

Figures 1-6 Archaeomonas striata Deflandre; Samples 338-26$4,140 \mathrm{~cm}$ (fig. 1, 2) and 340-9-4, $100 \mathrm{~cm}$.

Figure 7 Archaeomonas sp. 1; Sample 338-21-1, $145 \mathrm{~cm}$.

Figure 8 Archaeomonas oamaruensis Deflandre; Sample $340-9-4,100 \mathrm{~cm}$.

Figure 9 Archaeomonas japonica Deflandre; Sample 340-11. $4,110 \mathrm{~cm}$.

Figure 10 Archaeomonas dubia Deflandre; Sample 340-5-1, $80 \mathrm{~cm}$.

Figures 11, 12 Archaeomonas chenevieri Deflandre; Sample 340$3-4,110 \mathrm{~cm}$.

Figures 13,14 Archaeomonas cf. A. lefeburei Deflandre; Sample $340-9-1,120 \mathrm{~cm}$.

Figure 15 Archaeomonas paucispinosa Deflandre; Sample $340-11-4,110 \mathrm{~cm}$

Figure 16 Parachaeomonas challengeri n. sp.; Sample 340-9-4, $100 \mathrm{~cm}$; holotype.

Figure 17 Archaeomonas kreyenhagenensis Rampi; Sample $340-11-4,100 \mathrm{~cm}$.

Figure $18 \quad$ Archaeomonas sphaeroidea Deflandre; Sample 341$33-4,116 \mathrm{~cm}$.

Figure 19 Archaeomonas? sp. 2; Sample 340-9-4, $100 \mathrm{~cm}$.

Figure 20 Archaeomonadopis lagenula Deflandre; Sample $340-11-4,110 \mathrm{~cm}$.

Figures 21, 22 Archaeomonas norvegiensis n. sp.; Sample 340-2-1, $85 \mathrm{~cm}$; holotype.

Figures 23, 24 Archaeomonas heteroptera Deflandre; Samples $340-9-4,100 \mathrm{~cm}$ and 338-29-1. $94 \mathrm{~cm}$.

Figures 25,26 Archaeomonas cf. heteroptera Deflandre; Sample $341-33-4,116 \mathrm{~cm}$.

Figure 27 Litharchaeocystis glabra Rampi; Sample 340-10-4, $70 \mathrm{~cm}$.

Figures 28,29. Litharchaeocystis oamaruensis Deflandre; Sample 32 $340-11-4,110 \mathrm{~cm}$. Magnification fig. 32 2500×.

Figures 30, 31 Litharchaeocystis udintsevii n. sp.; Samples 340-1033

$4,70 \mathrm{~cm}$ and $338-27-4,111 \mathrm{~cm}$. Fig. 30 and 31 show the holotype. Magnification fig. 33 2000×.

Figures 34-36 Litharchaeocystis talwanii n. sp.; Sample 340-9-4, $100 \mathrm{~cm}$. Fig. 35 and 36 show the holotype. Magnification fig. $342500 \times$.

Figure 37 Litharchaeocystis costata Deflandre; Sample 340$11-4,110 \mathrm{~cm}$. 
PLATE 3
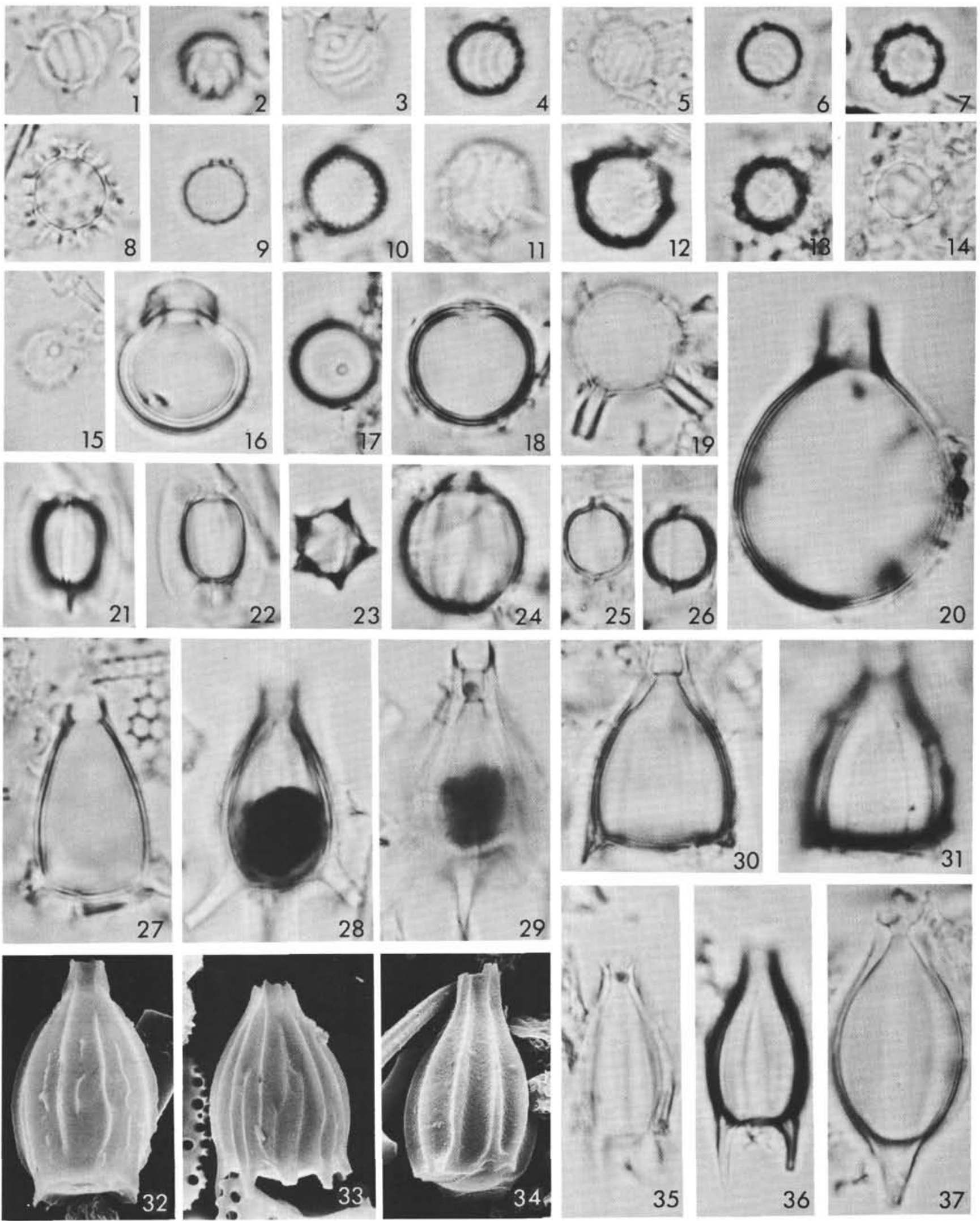
PLATE 4

Magnification $2000 \times$

Figure 1 Archaeomonas speciosa Deflandre; Sample 338-11$1,130 \mathrm{~cm}$.

Figures 2, 3 Archaeomonas areolata Deflandre; Sample 338-11$1,130 \mathrm{~cm}$.

Figures 4.5 Airchaeomonas helminthophora Deflandre; Sample 338-11-1, $130 \mathrm{~cm}$.

Figures 6,7,8 Litheusphaerella sp. 1; Samples 338-13-4, $90 \mathrm{~cm}$ and 341-34-3, $101 \mathrm{~cm}$ (fig. 8).

Figures 9, 10 Archaeomonas cf. A. dentata Deflandre; Sample $338-20-4,120 \mathrm{~cm}$.

Figures 12, 13 Archaeomonas cf. A. ovoidea Deflandre; Sample $338-8-4,120 \mathrm{~cm}$.

Figures 14, 15 Archaeomonas ovoidea Deflandre; Sample 341-324, $127 \mathrm{~cm}$.

Figures 11, 16 Archaeomonas sp. 3; Sample 341-27-4, $89 \mathrm{~cm}$.

Figures 17-21 Archaeosphaeridium ornatum Deflandre; Samples $341-33-4,116 \mathrm{~cm}$ (fig. 17, 18); 341-31-4, $127 \mathrm{~cm}$ (fig. 19); and $341-27-4,89 \mathrm{~cm}$. 
PLATE 4
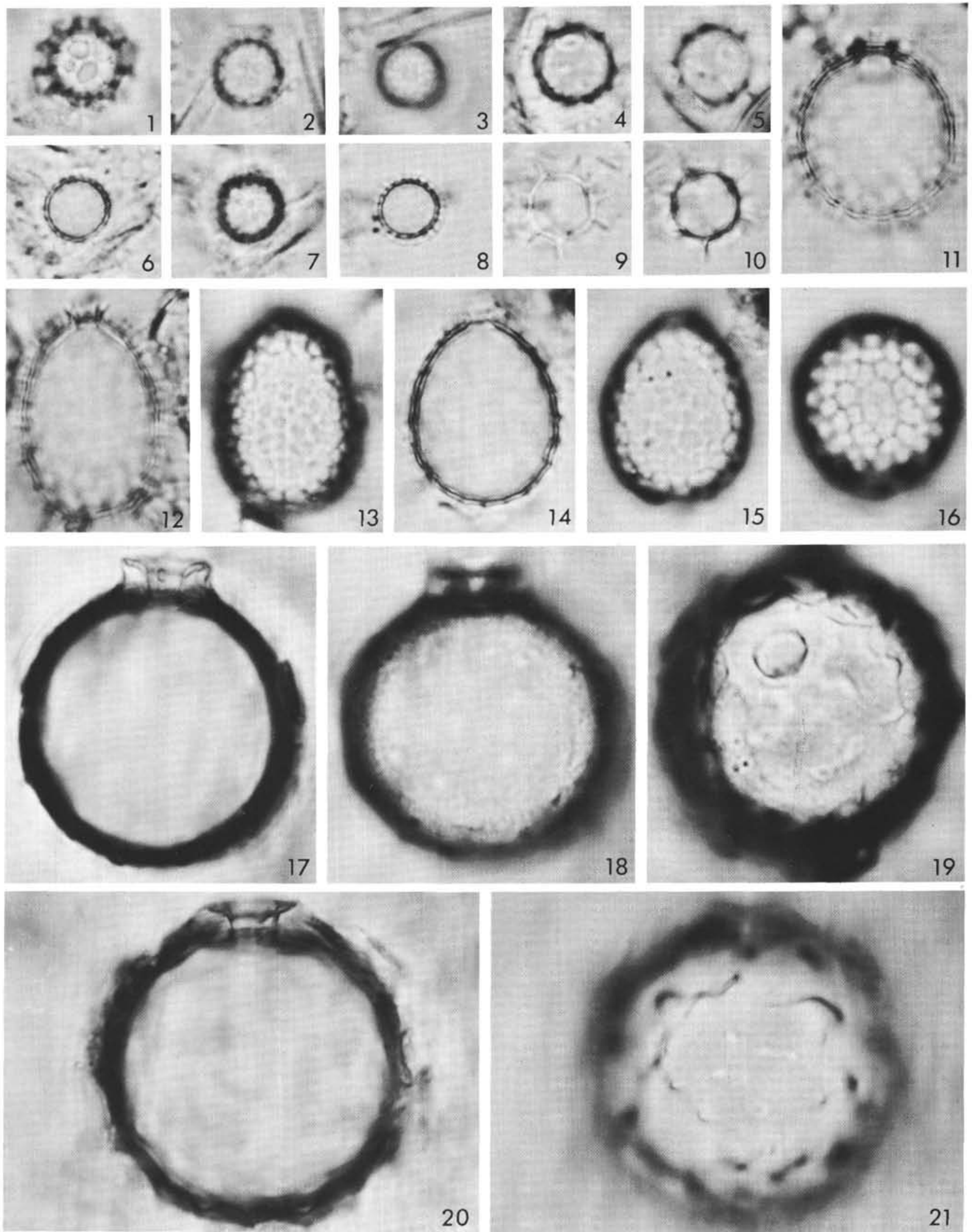


\section{PLATE 5}

Figures 1-7, Actiniscus pentasterias Ehrenberg; Samples 3419-11 34-3, $101 \mathrm{~cm}$ (fig. 1, 2, 5) and 341-27-4, $89 \mathrm{~cm}$ (fig. $3,6,7,9-11$ ); magnification $1800 \times$ (fig. 1, 3, 5); $2000 \times$ (fig. 2); $1500 \times$ (fig. 6); $2500 \times$ (fig. 4, 7, 9); $1300 \times$ (fig. 10, 11).

Figures 8, 12, Actiniscus sp.; Sample 338-8-4, $120 \mathrm{~cm}$; magnifica15 tion $750 \times$ and $1500 \times$ (fig. 12, 15).

Figures 13, 14 Actiniscus elongatus Dumitrica; Sample 341-30-4, $90 \mathrm{~cm}$; magnification $2500 \times$.

Figure 16 Calcipedinium quadripes Dumitrica; Sample 338-84, $120 \mathrm{~cm}$; magnification $1800 \times$.

Figures 17-19 Actiniscus tetrasterias Ehrenberg; Samples 341-27$4,89 \mathrm{~cm}$ (fig. 17) and 338-14-1, $100 \mathrm{~cm}$; magnification $2000 \times$ (fig. 17,18 ) and $2500 \times$.

Figure 20 Carduifolia gracilis Hovasse; Sample 340-9-4, 100 $\mathrm{cm}$; magnification $1500 \times$. 


\section{PLATE 5}
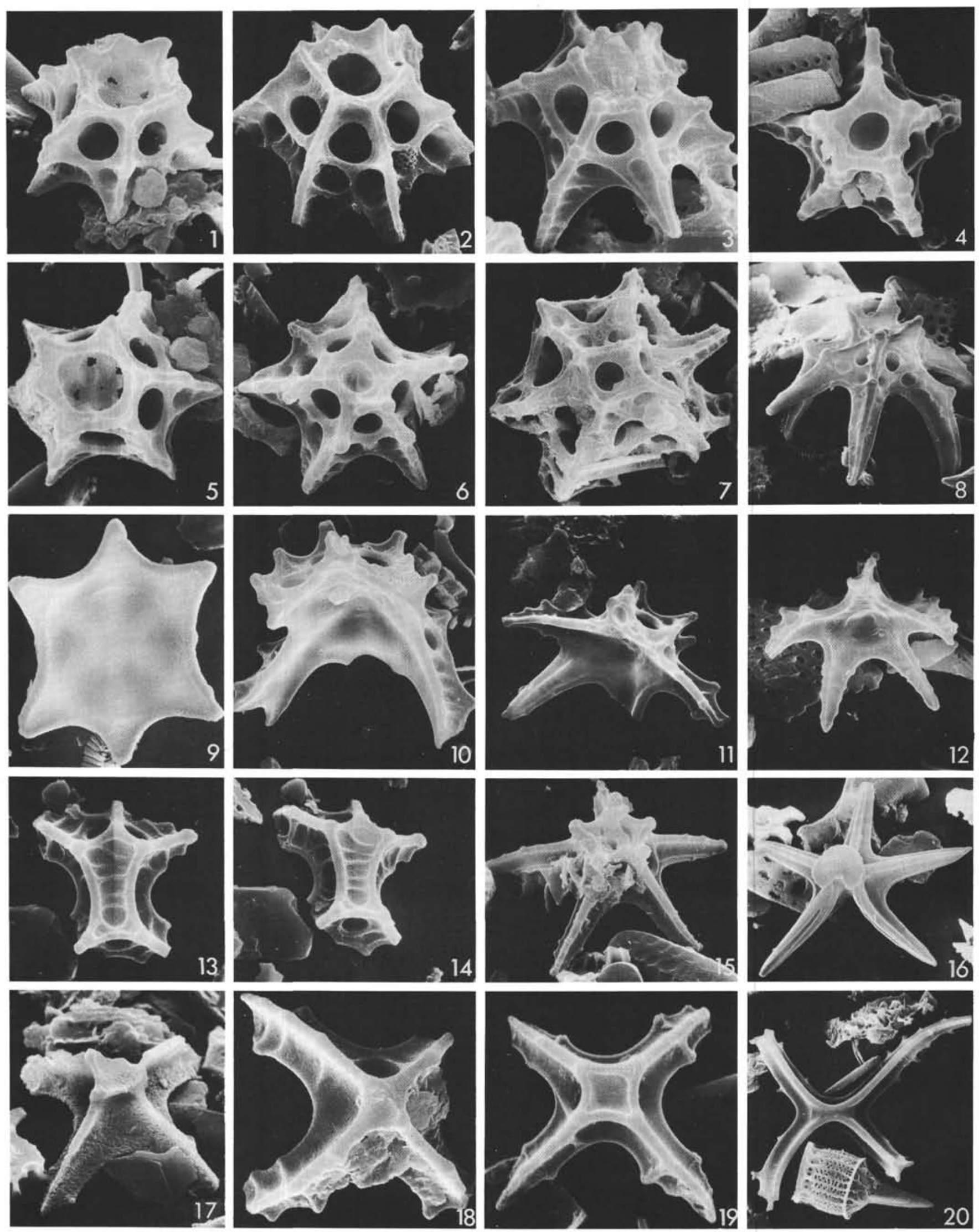


\section{PLATE 6}

Figures 1-8 Foliactiniscus atlanticus n. sp.; Samples 338-18-1, $140 \mathrm{~cm}$ and 338-14-1, $100 \mathrm{~cm}$ (fig. 2, 3); magnification $2500 \times$ (fig. 1, 3, 5-7), $2200 \times$ (fig. 4, 8). Fig. 6 is the holotype.

Figures 9, $\quad$ Actiniscus pentasterias Ehrenberg; Samples 33813-16 $\quad 11-1,130 \mathrm{~cm}, 338-13-4,90 \mathrm{~cm}$ (fig. 13-15) and 338$14-1,100 \mathrm{~cm}$ (fig. 16); magnification $1500 \times$.

Figures 10-12 Foliactiniscus folia (Hovasse) Dumitrica; Samples $338-14-1,100 \mathrm{~cm}, 338-13-4,90 \mathrm{~cm}$ and 338-18-1, $140 \mathrm{~cm}$; magnification $1500 \times$ and $1300 \times$ (fig. 11).

Figures 17-20 Pseudammodochium sp.; Samples 340-9-4, $100 \mathrm{~cm}$ (fig. 17) and 339-11-1, $100 \mathrm{~cm}$; magnification $1500 \times, 1300 \times, 1800 \times, 1000 \times$, respectively. 
PLATE 6
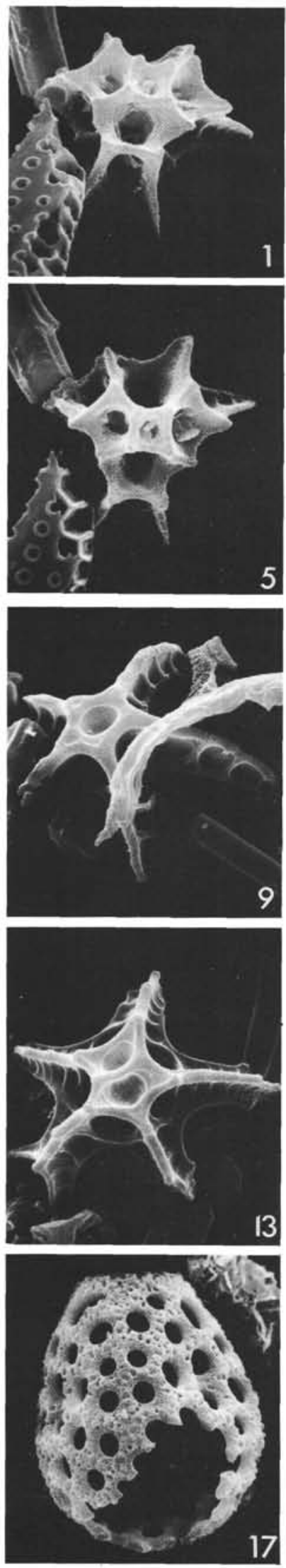
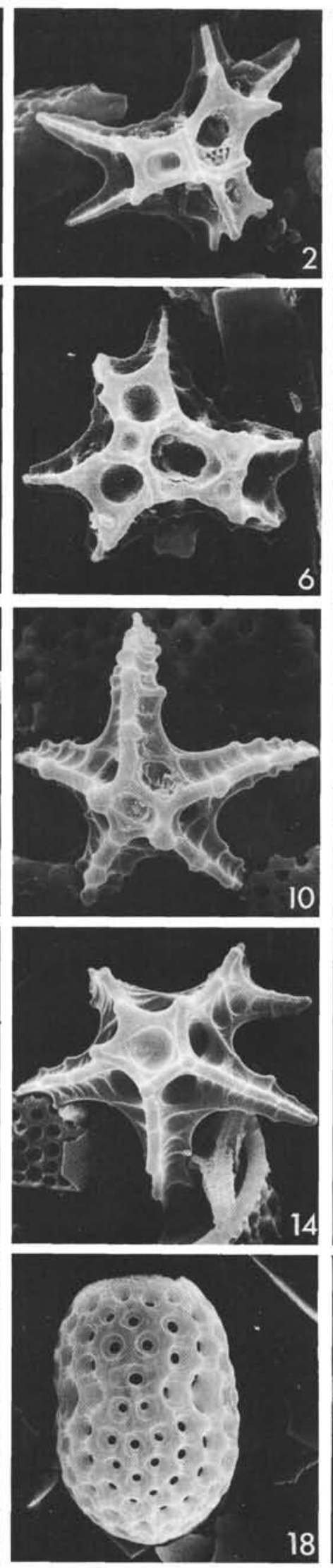
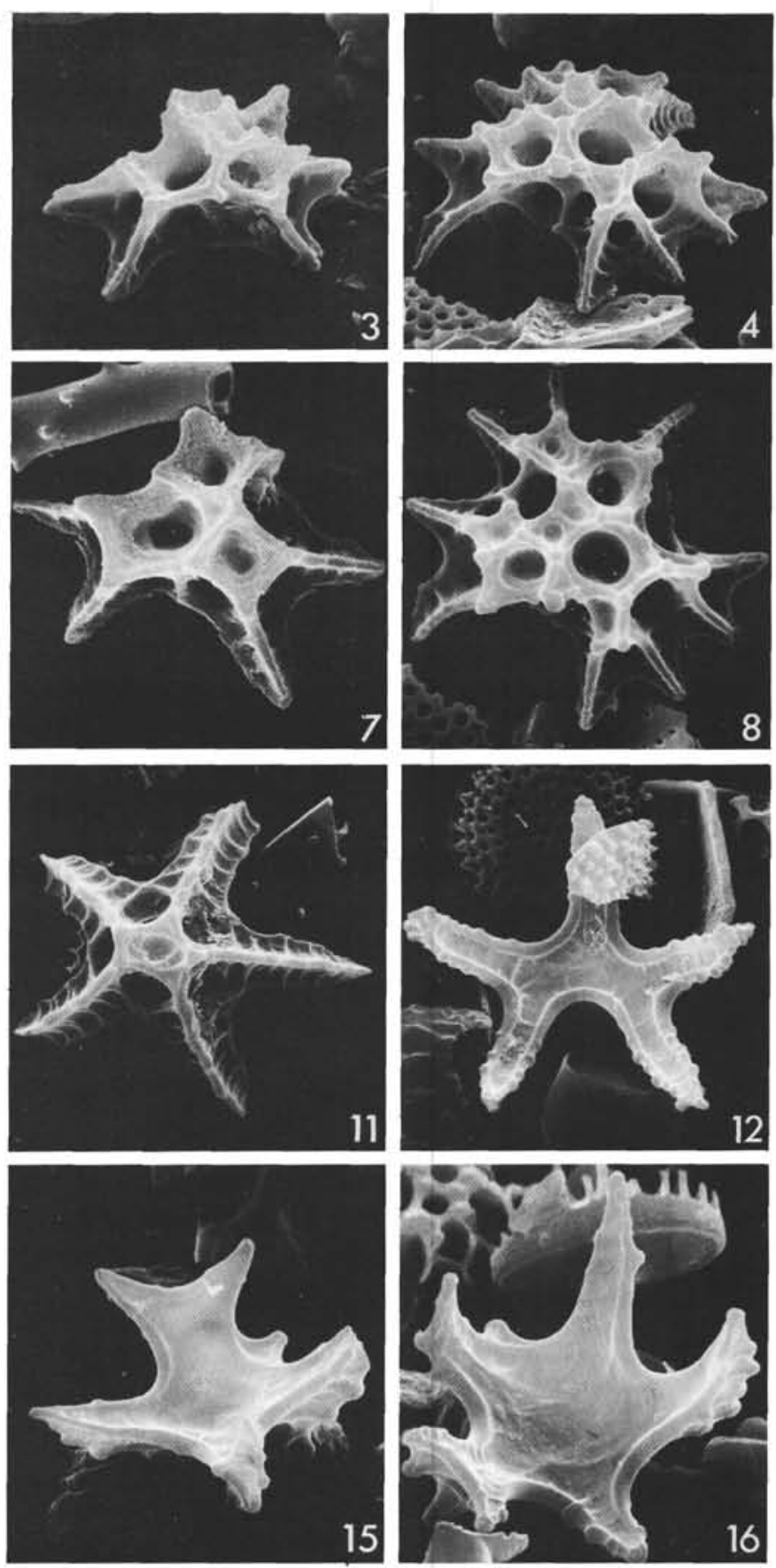

1
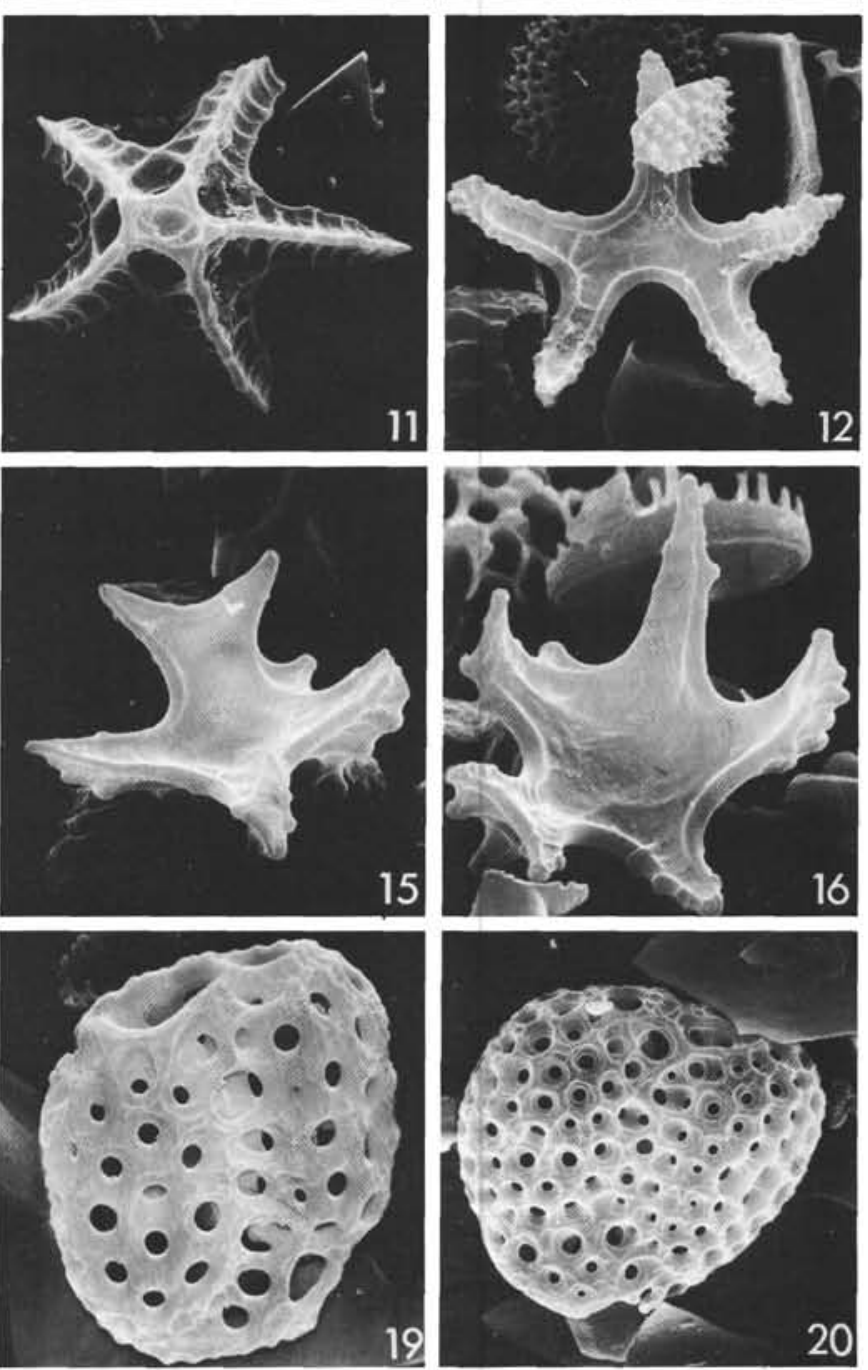


\section{PLATE 7}

Figures 1-16 Parathranium intermedium Hovasse; Samples 34127-4, 89 cm (fig. 1, 5); 338-18-1, $140 \mathrm{~cm}$ (fig. 2, 3, 7, $10,11) ; 338-11-1,130 \mathrm{~cm}$ (fig. 4, 6, 8, 9, 12, 13); $338-8-4,120 \mathrm{~cm}$ (fig. 14-16); magnification 2000X (fig. 1, 4-8, 10); $2500 \times$ (fig. 2, 11); 2300 $\times$ (fig. 3); $1500 \times$ (fig. 9, 12, 13), 1400× (fig. 14-16).

Figures 17, 18 Clathropyxidella similis Deflandre; 340-3-4, 110 $\mathrm{cm}$; magnification $4500 \times$

Figures 19, 20 Pseudorocella barbadiensis Deflandre; Sample 339$11-1,100 \mathrm{~cm}$; magnification $3000 \times$ and $2500 \times$. 
PLATE 7
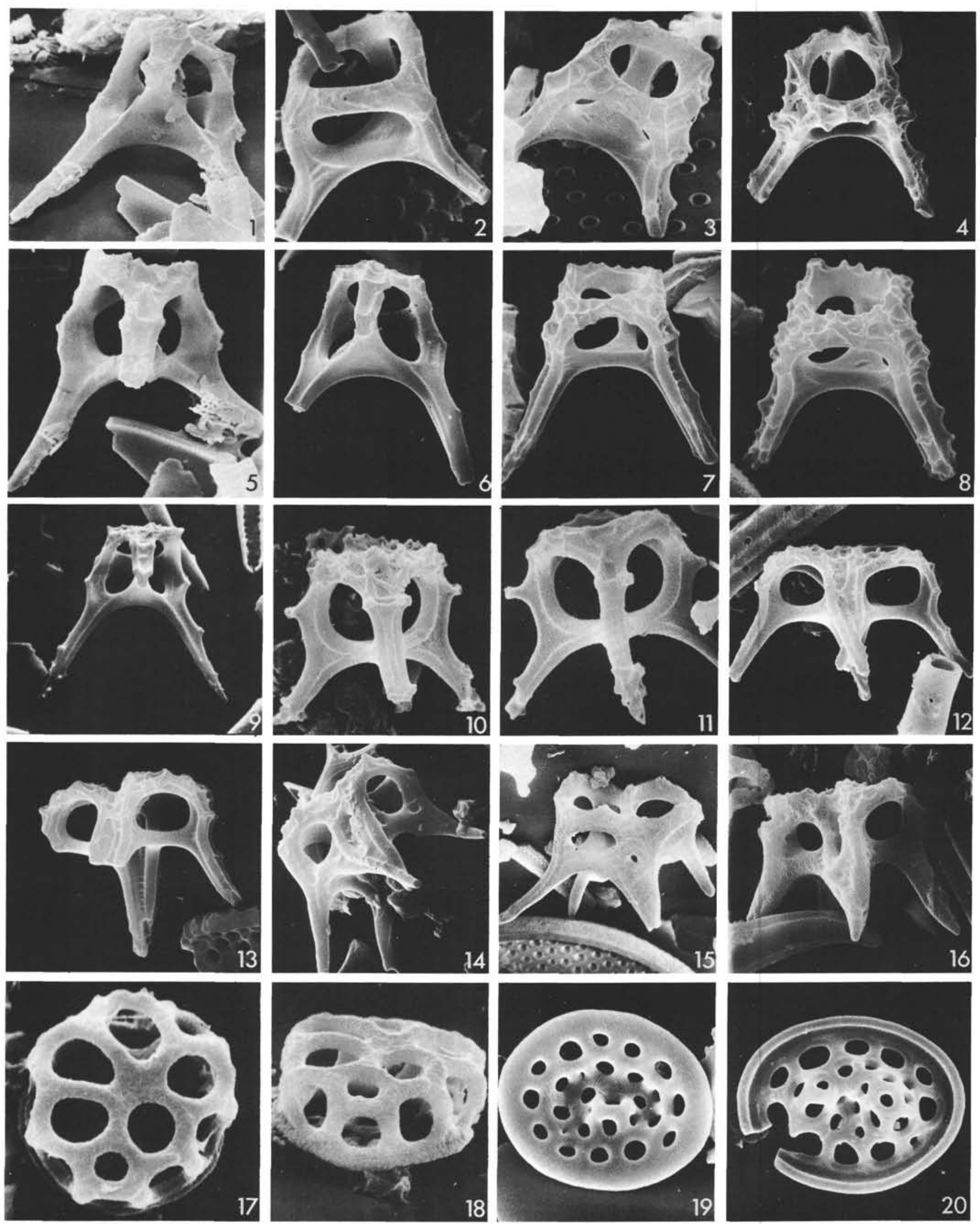


\section{PLATE 8}

Figures 1-8, 12 Ebridians. Gen. et sp. indet.; Samples 338-13-4, 90 cm (fig. 1, 3, 5, 7); 338-14-1, 100 cm (fig. 2, 6); 338$27-4,111 \mathrm{~cm}$ (fig. 4, 8); and 340-9-4, $100 \mathrm{~cm}$ (fig. 12); magnification $650 \times$ (fig. 1, 5); $800 \times$ (fig. 2, 6); $1500 \times$ (fig. 3, 7, 12); $1600 \times$ (fig. 4); and $2000 \times$ (fig. 8).

Figures 9-11 “Falsebria" sp.; Samples 338-18-1, $140 \mathrm{~cm}$; 338-11$1,130 \mathrm{~cm}$; and $339-11-1,100 \mathrm{~cm}$; magnification $1000 \times$ (fig. 9, 10) and $2000 \times$ (fig. 11).

Figures 13, 14 Ammodochium novum $\mathrm{n}$. sp.; Sample 339-11-1, 100 $\mathrm{cm}$; magnification $1500 \times$. Fig. 14 is the holotype.

Figures 15, 16 Ammodochium complexum Dumitrica and PerchNielsen n. sp.; Samples 340-9-4, $100 \mathrm{~cm}$ and 338$27-4,111 \mathrm{~cm}$; magnification $1500 \times$ and $1200 \times$ (fig. 16).

Figures 17-19 Ammodochium rectangulare (Schulz) Deflandre; Samples 340-11-4, $110 \mathrm{~cm}$ (fig. 17) and 341-27-4, $89 \mathrm{~cm}$; magnification $1500 \times$ (fig. 17) and $2000 \times$.

Figure 20 Ammodochium cf. A. prismaticum Hovasse; Sample $338-11-1,130 \mathrm{~cm}$; magnification $1500 \times$. 


\section{PLATE 8}
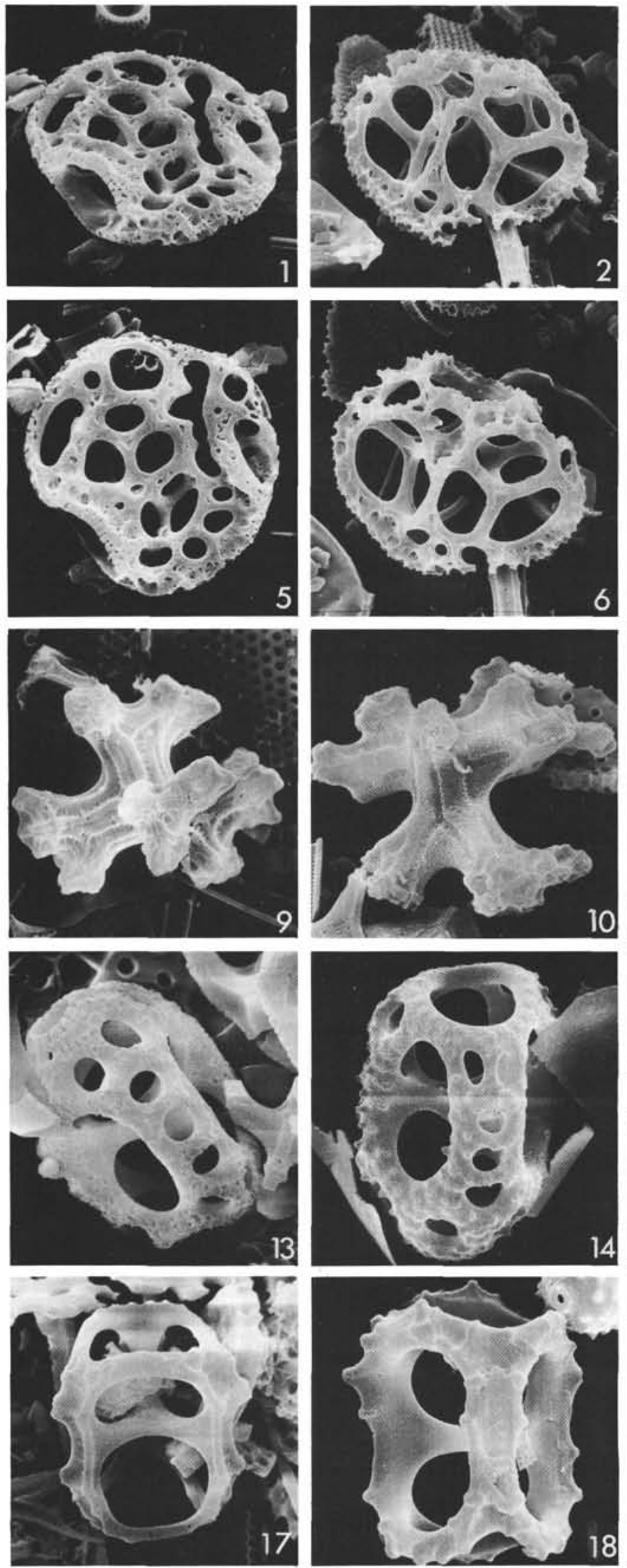
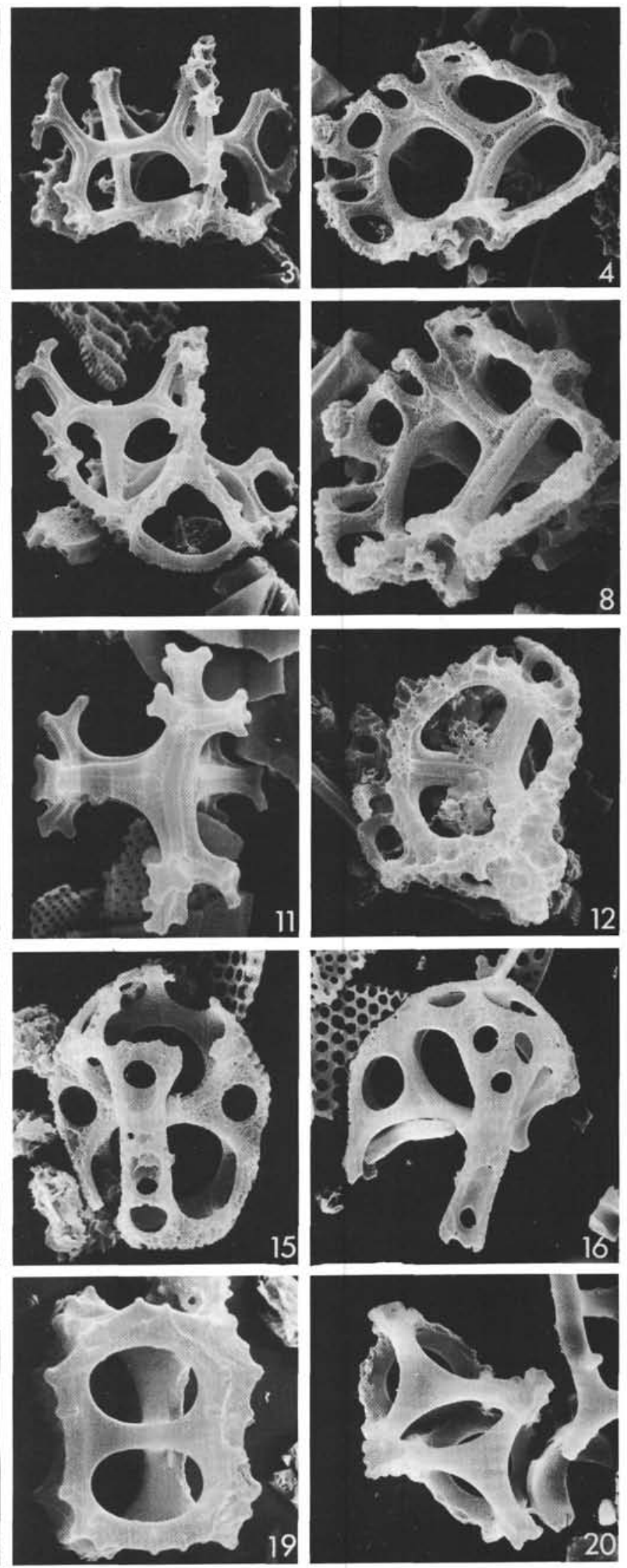


\section{PLATE 9}

Figures 1-5 Ebriopsis cornuta Dumitrica and Perch-Nielsen; Samples 340-2-1, $85 \mathrm{~cm}$ (fig. 1); 340-9-4, $100 \mathrm{~cm}$ (fig. 2, 3); and $340-10-4,70 \mathrm{~cm}$ (fig. 4, 5); magnification $1500 \times$ (fig. 1-3) and $1000 \times$ (fig. 4, $5)$.

Figures 6-8 Ebriopsis crenulata Hovasse; Samples 340-2-1, 85 $\mathrm{cm}$; 340-9-4, $100 \mathrm{~cm}$; and 338-27-4, $111 \mathrm{~cm}$; magnification $1500 \times, 1000 \times$, and $1200 \times$, respectively.

Figure 9

Parebria valida Deflandre; Sample 340-9-4, 100 $\mathrm{cm}$; magnification $1500 \times$.

Figures 10-19 Haplohermesinum simplex (Schulz) Hovasse; $20 ? 21$ ? Samples 338-14-1, $100 \mathrm{~cm}$ (fig. 10, 14); 338-11-1, $130 \mathrm{~cm}$ (fig. 11, 15, 18-21); 338-13-4, $90 \mathrm{~cm}$ (fig. 12, 16); and 338-27-4, $111 \mathrm{~cm}$ (fig. 13, 17); magnification $1300 \times$ (fig. 10,14); $1500 \times$ (fig. 11, 15, 12, 16, 17); $2000 \times$ (fig. 13); and $2200 \times$ (fig. 20, 21). 
PLATE 9
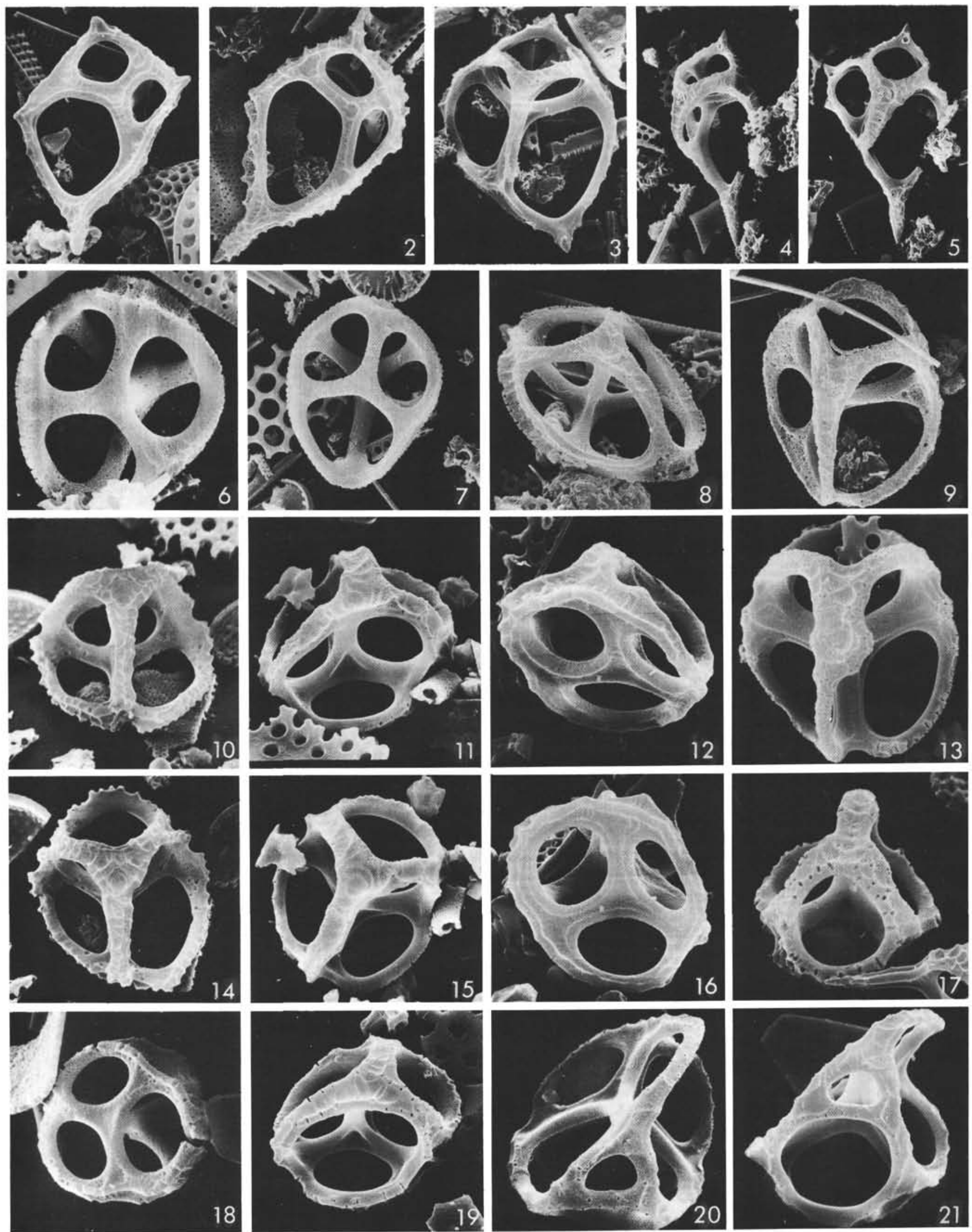


\section{PLATE 10}

Figures 1-8 Hermesinopsis caulleryi Deflandre; Samples 338$27-4,111 \mathrm{~cm}$ (fig. 1, 2); 338-18-1, $140 \mathrm{~cm}$ (fig. 3, 4); and $339-11-1,100 \mathrm{~cm}$ (fig. 5-8).

Figure 9 Ebridian. Gen. et sp. indet.; Sample 338-13-4, 90 $\mathrm{cm}$; magnification $800 \times$.

Figures 10,14 Parebriopsis symmetrica Dumitrica and PerchNielsen n. sp.; Sample Vema $43 / 28-220 \mathrm{~cm}$; magnification $2000 \times$ (Holotype, fig. 10), $800 \times$.

Figure 11 Ammodochium complexum Dumitrica and PerchNielsen n. sp.; Sample Vema 43/28-220 cm; magnification $3000 \times$. Holotype.

Figure 12 Hermesinum geminum Dumitrica and PerchNielsen, broken specimen; Sample 338-21-1, 145 $\mathrm{cm}$; magnification $800 \times$.

Figure 13 Ebriopsis cornuta Dumitrica and Perch-Nielsen; Sample 338-21-1, $145 \mathrm{~cm}$; magnification $800 \times$.

Figures 15-17 Parathranium intermedium Hovasse; Samples 341$27-4,89 \mathrm{~cm} ; 338-8-4,120 \mathrm{~cm}$; and $341-33-4,116$ $\mathrm{cm}$; magnification $800 \times$.

Figures 18, 19 Siliceous dinoflagellate?; Sample 340-2-1, $85 \mathrm{~cm}$; magnification $2000 \times$. 

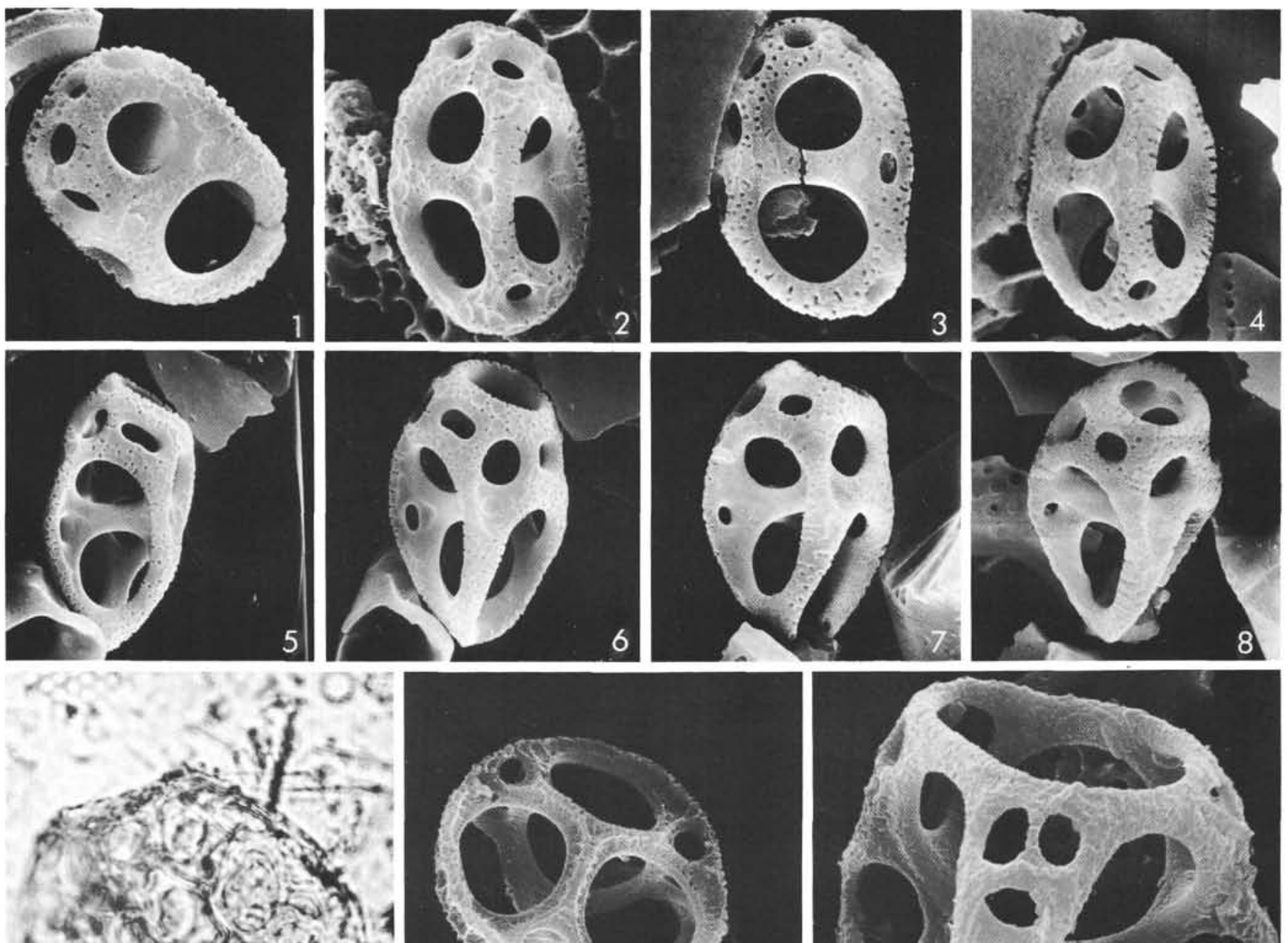

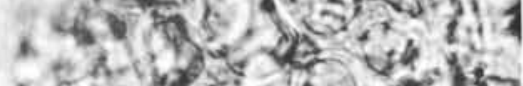

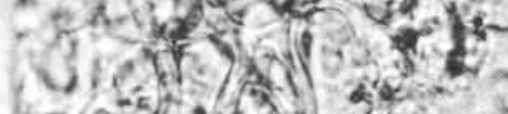

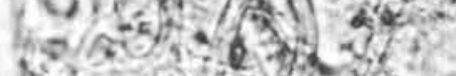

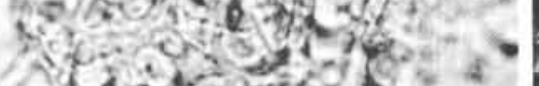

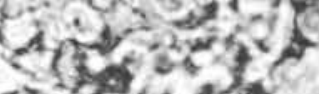
(n)

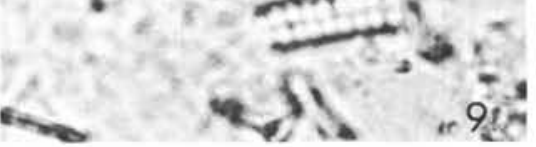
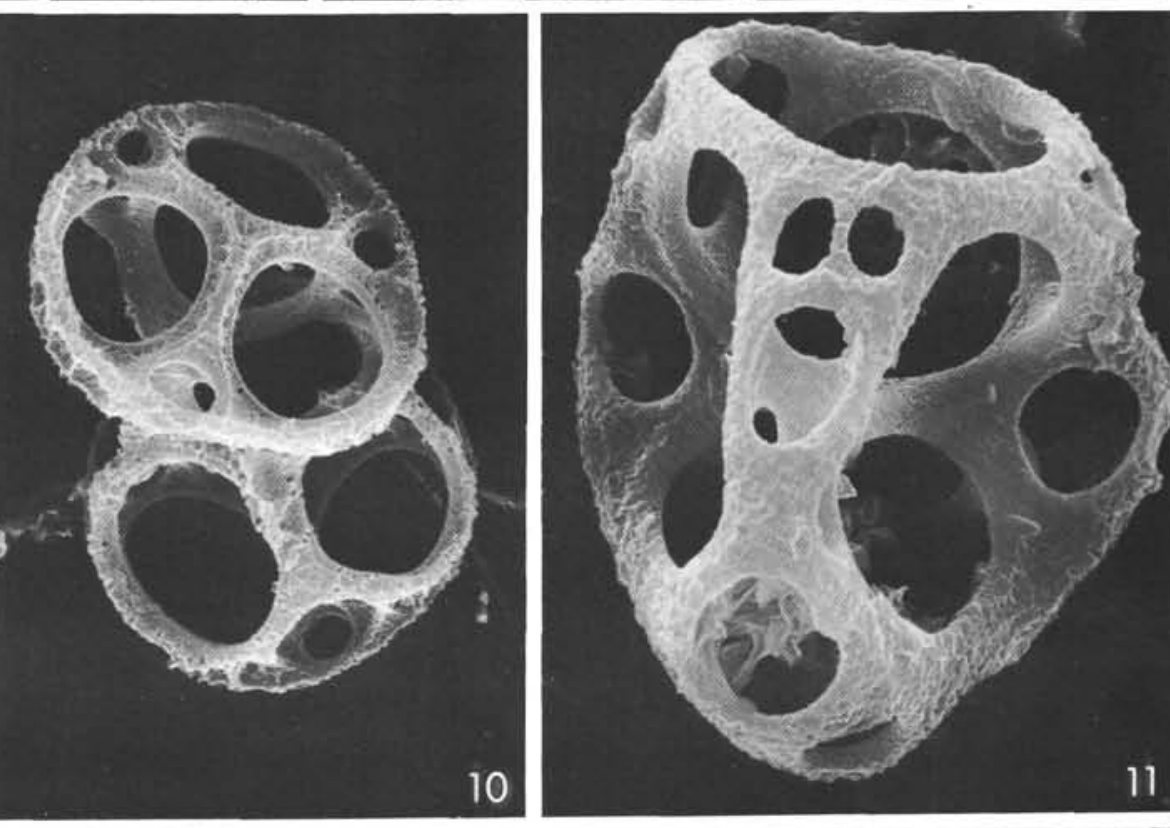

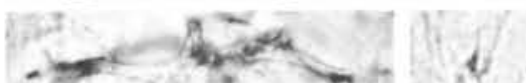
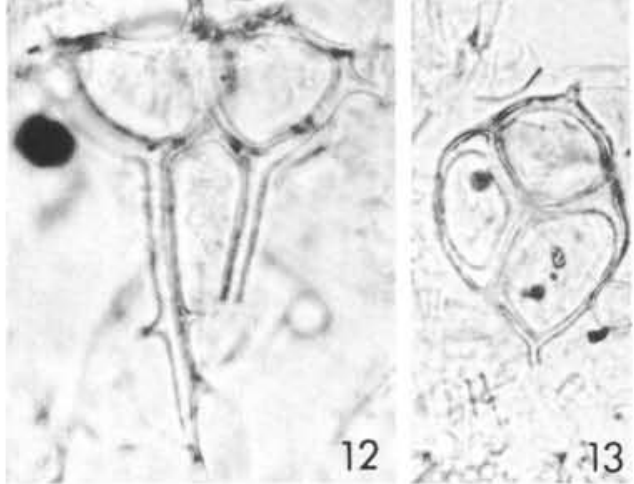

$$
3 x^{2}-4
$$

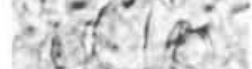

ingen
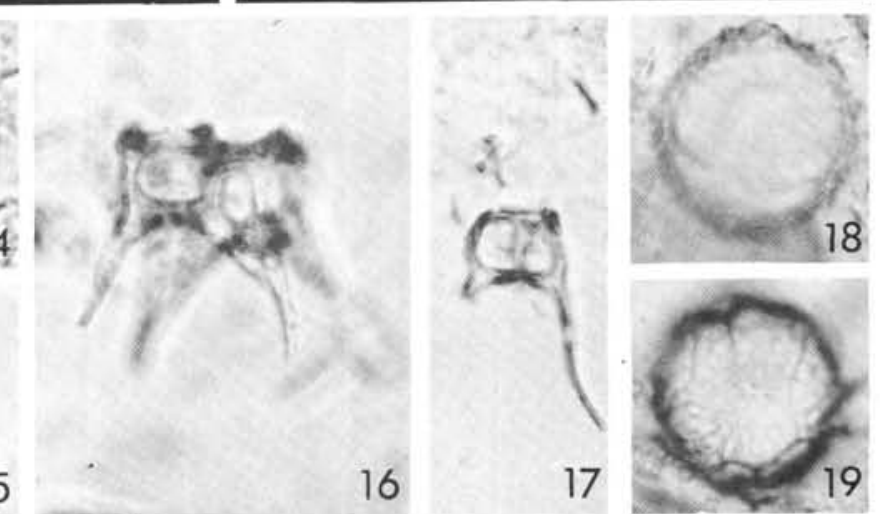